This is an Accepted Manuscript of the article Aguilar-González, B., Navas, G., Brun, C., Aguilar-Umaña, A., \& Cerdán, P. (2018). Socio-ecological distribution conflicts in the mining sector in Guatemala (2005-2013): Deep rooted injustice and weak environmental governance. The Extractive Industries and Society, 5(3), 240-254, available online at https://doi.org/10.1016/i.exis.2018.02.002. (C2018. This manuscript version is made available under the CC-BY-NC-ND 4.0 license. 


\title{
Socio-ecological distribution conflicts in the mining sector in Guatemala (2005-2013): Deep rooted injustice and weak environmental governance
}

\author{
Bernardo Aguilar-González ${ }^{\mathrm{a} 1}$, Grettel Navas ${ }^{\mathrm{b}}$, Carole Brunc, Andrea Aguilar-Umaña ${ }^{\mathrm{d}}$, \\ Paloma Cerdáne \\ a Fundación Neotrópica, San José, Costa Rica, baguilar@neotropica.org; \\ ${ }^{b}$ Fundación Neotrópica, San José, Costa Rica. Currently ICTA (Institut de Ciència i Tecnologia Ambientals), Universitat \\ Autonoma de Barcelona, Barcelona, Spain, grettelnavas98@gmail.com; \\ c Fundación Neotrópica, San José, Costa Rica, carole-brun@hotmail.com ; \\ d Fundación Neotrópica, San José, Costa Rica, aaguilarumana@gmail.com; \\ e Fundación Neotrópica, San José, Costa Rica, pcerdan@neotropica.org
}

${ }^{1}$ Corresponding author: baguilar@neotropica.org. Fundación Neotrópica, Calle 49, San Pedro de Montes de Oca, San José, Costa Rica. PO Box 236-1002 Paseo de los Estudiantes, San José, Costa Rica. Tel (506) 22532130. Fax (506) 22534210. Mobile (506) 89206174. 


\title{
Socio-ecological distribution conflicts in the mining sector in Guatemala (2005-2013): Deep rooted injustice and weak environmental governance
}

\begin{abstract}
This study characterizes ecological distribution conflicts (EDC) related to the mining industry and derives a series of political implications for Guatemala. The characterization includes a placement in the context of Central America, regional location, intensity of the EDC and the trends in social and environmental consequences, with special emphasis on the groups of social actors affected and the degree to which the institutional framework does not provide effective means of participatory environmental governance. The time period covers 2005 to 2013. In order to understand trends in actor behavior and diverse moments of high intensity we introduce the use of action and response timelines as a methodology for EDC analysis. We propose the notions of embedded conflicts to describe their relation with the structural social conditions prevailing in the country and swarms of conflicts to describe their escalation through time. We conclude that conflictivity is inherent to the unsustainable characteristics of metallic mining and is aggravated by Guatemala's history of social inequality and power concentration. The attempts to reduce "conflictivity" through CSR have been insufficient in addressing these structural conditions. EDCs may have helped create a positive environment for creative forces to seek sustainability and justice in Guatemala's development model.
\end{abstract}

\section{Keywords:}

Environmental Justice Atlas (EJAtlas); Ecological Distribution Conflict; Nested Conflict; Conflict Swarm; Indigenous Community Consultations; Guatemala Mining

\section{Introduction}

In the present study, we present some of the results of research carried on for the United Nations Development Program in Guatemala focused on a characterization of the ecological distribution conflicts (EDC) generated by the mining industry between 2005 and 2013. For this, we characterized the Guatemalan conflict situation within the Central American context. Next, we specifically sought to identify and locate regionally the main mining projects (exploration and exploitation licenses) and their related EDCs. We also sought to identify the main social and 
ecological consequences of these conflicts with special emphasis on their patterns of intensity. In order to understand the social dynamics of the activity, we characterized the main actors and the evolution of their interests and the consequences on them (Aguilar González, 2013).

We also analyzed critically the role of the national and local institutional framework in addressing this conflictivity. We wish to determine if the role of the State has been active or deficient as an institutional mediator leading to conflictivity by action or omission. The analysis synthetizes the legal and institutional framework and characterizes its contributions to the development/resolution of mining conflicts. (Barriga, et al., 2007; Paniagua, 2007; Brenner, 2010). We also evaluate, albeit more succinctly, the effectiveness of the actions taken by extractive companies through corporate social responsibility (CSR) programs.

We use a Political Ecology theoretical framework focused on the study of EDC that are caused by an increase in the social metabolism ${ }^{1}$ (an increase in the extraction of energy and materials) generated by the neo-extractivist model of development implemented in the last 2 decades (Martínez-Alier, 2004; Svampa, 2013). We understand mining related EDCs being the result of an unfair the distribution to/by social actors of the costs and benefits of the use/appropriation of environmental space. (Martínez-Alier, 2004; Walter, 2009). The concept of environmental space introduces in the measurement of equality, beyond the distribution of incomes and economic rewards, the recognition of the human right to the enjoyment of benefits from environmental services that are provided by ecosystem functions. These services and the ecosystems where they come from constitute the common heritage that is denominated environmental space (Hille, 1997).

In this sense, the focus of our analysis sought to provide evidence on the asymmetries of power that lead to the unjust distribution of the environmental space related to the mining activity. These asymmetries result in environmental injustice (Martínez-Alier, 2008).

This type of spatial/equity documentation fits the line of research on EDC that has been led by the Autonomous University of Barcelona through the Environmental Justice Atlas (EJAtlas -

\footnotetext{
${ }^{1}$ The concept of social metabolism refers to the set of flows of materials and energy that occur between Nature and society, and between different societies, carried out with a specific cultural form (Toledo, 2013).
} 
http://ejatlas.org) and its related research projects. Environmental activist organizations like OCMAL (Observatory for Mining Conflicts in Latin America), alongside academic researchers like the EJOLT project (www.ejolt.org) and other research projects have produced free access inventories and conflict maps around the world which seek to highlight these asymmetries and articulate Environmental Justice movements worldwide.

\section{Qualitative and Quantitative Methods}

A mixed qualitative and quantitative methodology was used for the comprehension of the Guatemalan socio-ecological context, as well as for gathering and analyzing information on the EDCs related to mining activities between 2005 and 2013. It included literature review, data collection and analysis through descriptive statistical tools.

The literature reviewed included research on case studies at a local level, national studies on mining conflicts, environmental diagnostics, reports on the situation of human rights of indigenous groups, publications from business associations, news sources and the websites of several organizations. Through the help of the UNDP, we had access to the Ministry of Energy and Mining's (MEM) database and maps of exploration and exploitation licenses (October 2013). They were complemented by the available online databases of active mining rights per department in (December 2014). This allowed disaggregation and descriptive statistical analysis by mining types.

To build a preliminary list of the most important conflicts and evaluate their intensity, an online survey of key informants was carried out, using a snowball sampling approach. We delivered an instrument designed to compile and characterize a list of conflicts in accordance to the levels of intensity defined in our theoretical framework. The instrument was delivered to 16 actors and key experts.

We evaluated the intensity of the conflicts using an adaption of the scale used by the EJAtlas. The Atlas includes as parameters the spatial and visibility level of mobilization and organization of actors mobilizing and the level of violence. Our scale seeks to enrich this approach gauging the level of organization and complexity of all actors, the spatial scale of the conflict itself (as compared to the national/regional socio-ecological context where it is happening), the level of 
tension and social violence and the scale and visibility of mobilization (Aguilar-González, et al., 2015).

This scale is consequent with the logic of other scales of conflictivity. In relation to the scale of political conflicts of the Heidelberg Institute for International Conflict Research (HIIK), our scale fits within the realm of what their technical studies consider low and medium intensity conflicts. The scales of high intensity in this metric refers to those conflicts that result in war (Heidelberg Institute for International Conflict Research, 2015).

We also adopt a conflict evolution model of seven functional stages, going from the formation or latency of conflict to crisis, through stages of emergence and escalation. Once the crisis has finished, it recognizes the steps of de-escalation, maturity, and transformation (Bedoya, et al., 2010).

Fieldwork was carried out in Guatemala in March 2015 with eight meetings and semi-structured interviews with key actors and experts from environmental organizations, indigenous/human rights groups, research centers, unions, mining companies, government entities and academic centers. Our academic and technical informants included Raúl Maas and Lourdes Molina, researchers from the Instituto de Agricultura, Recursos Naturales of the Raúl Landivar University (IARNA-URL) and the Instituto Centroamericano de Estudios Fiscales (ICEFI). These interviews helped us complement our literature review regarding the technical aspects of the social, economic and environmental consequences of the mining activity in Guatemala and the interests, views and actions of diverse social actors.

From the mining industry sector we had interviews with Mario Marroquín, Executive Director of Goldcorp (Montana Exploradora) and Mario Orellana, president of the Chamber of Extractive Industries (GREMIEXT). We also met with Guillermo Monroy, Laura Retolaza and José Zepeda, representatives of Minera San Rafael. We sought to assess their perspective on similar issues as those described above and to gain a more immediate sense of the industry's CSR programs.

We enriched our assessment on actor's perspectives, consequences of the activity and the institutional preparedness of Guatemala to address the conflicts generated by the activity through 
two sources. We met with representatives of the Dialogue and Citizen Participation Unit of the Vice-ministry of Sustainable Development, Mayra Quiñonez, Otto Reyes, Sandy Polando and Julio César Chacón. We also attended an International Seminar on Transparency and Extractive Industries organized by local NGOs with international support from Transparency International.

Finally we were able to meet with two representatives from the NGO and community activist sector: Yolanda Oquelí from the community of La Puya and Magali Rey Rosa from the Savia School of Ecologist Thought. We gathered from them a first-hand notion of the perspective of these organized groups which resist mining activities.

We used discourse analysis (Sayago, 2014) to identify individual and group interests from actors as well as the power relations that characterize them. The information gathered through the literature survey, key informant survey and fieldwork was complemented by technical consultation with EJAtlas and OCMAL team members. The final ranking of conflicts was done using the group "brainstorming" method (Osborn, 1963).

We located the conflicts geographically based on licensing map created by previous research (ICEFI, 2014). Information was compiled for each selected conflict, through a summarized form based on the EJAtlas data form. For selected conflicts, graphics of action and response by actors through time were elaborated in order to understand the evolution of the complexity and intensity of the conflicts as done elsewhere in Central America for the landmark Crucitas mining conflict (Aguilar González, et al., 2012).

\section{Results and Discussion}

In order to frame the presentation of results we briefly present the socio-historical context of mining EDCs in Guatemala. We follow with a description of the geographic and temporal trends found in the appropriation of environmental space by mining projects. We close with a focus on the institutional framework relative to our results.

\subsection{The Central American Context of Mining Conflictivy}


The EJAtlas documents EDC (Temper, et al., 2015a; Temper, et al., 2015b). Since 2014 the documentation of these conflicts accelerated in Central America through the work of diverse organizations academic and on the ground contributors (Temper, et al., 2015a; Temper, et al., 2015b).

This documentation has allowed a statistical political ecology analysis in collaboration between the Universidad del Valle from Cali, Colombia, the University of Barcelona's ICTA institute and Fundación Neotrópica under the umbrella of the MESOCA-ANCA project. Of all Central American conflicts documented up to 2015 (Figure 1), the majority are registered in Guatemala with $27.5 \%$ of the 80 conflicts included until then, followed by Panama (18.8\%) and Honduras (17.5\%) (Navas, 2016).

Figure 2 shows us the registry of 80 conflicts up until 2015 in Central America. From these, 29\% were conflicts related to mining activities (more than a third of them appear in Guatemala). Conflicts related to water management are $24 \%$ of the total. These include conflicts related to hydroelectric projects. Those categories that relate to the appropriation of biomass and physical space, mostly by plantation activities and for biodiversity conservation are $25 \%$ of the total. Conflicts that relate to tourism are $9 \%$ of the total, mostly concentrated in Costa Rica. Fossil fuel energy shows a $9 \%$ of all conflicts while the record also shows conflicts from logistical infrastructure development (related to the Panama Canal and to projects such as Nicaragua's Grand Canal) and real estate development (5\%) (Navas, 2016).

These results confirm the conclusions of several studies which have already developed accounts for the region of the social and environmental impacts of neo-extractivism in terms of industries such as mining (Aguilar, et al., 2015; Alemancia, et al., 2015). Several other trends that characterize this conflictivity are worth presenting for the purposes of these results. These were part of the conclusions of the II Latin American Conference on Environmental Conflicts (COLCA). EDC in Central America have been increasing in numbers in the last decades, coinciding with the increase in neo-extractive activities. Figure 3 shows us this trend as of the EDC beginning each year according to the EJAtlas with peaks in 2006-2007 and 2011-2013. The trend line in red captures the increase detected. 


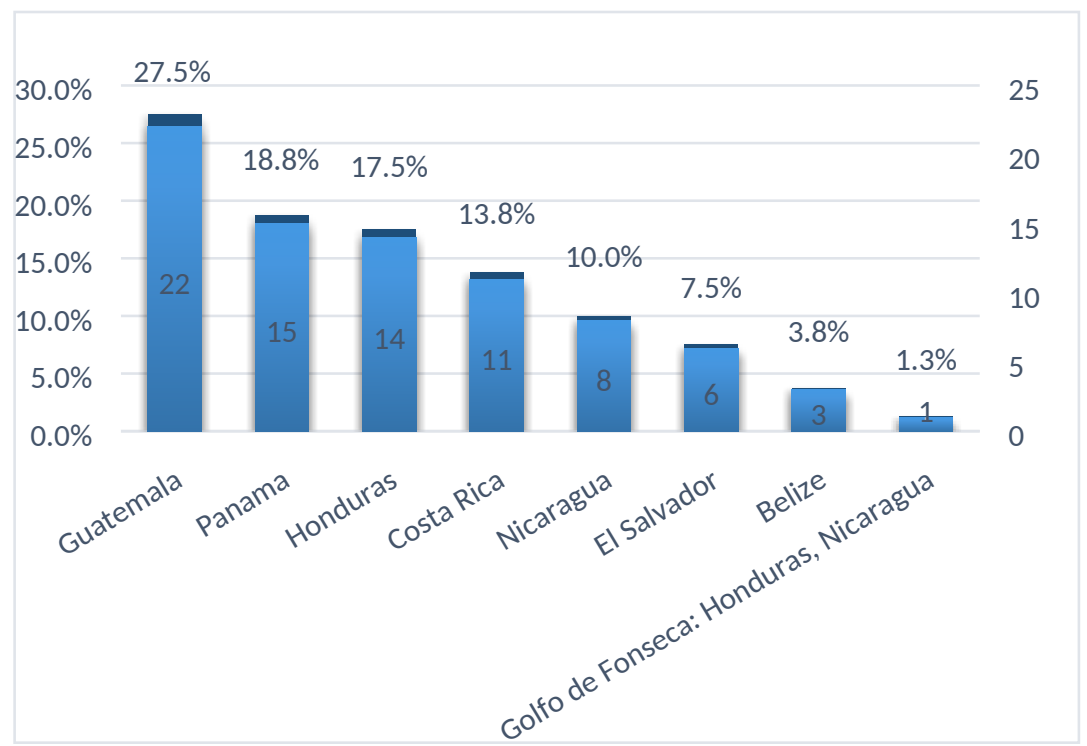

Figure 1- Ecological Distribution Conflicts by country in Central America according to the EJAtlas. Source: Navas (2016) for the MESOCA-ANCA Project.

Figure 2- Percentage of EDC in Central America by Metabolic Sector. Source: Navas (2016) for the MESOCA-ANCA Project. 


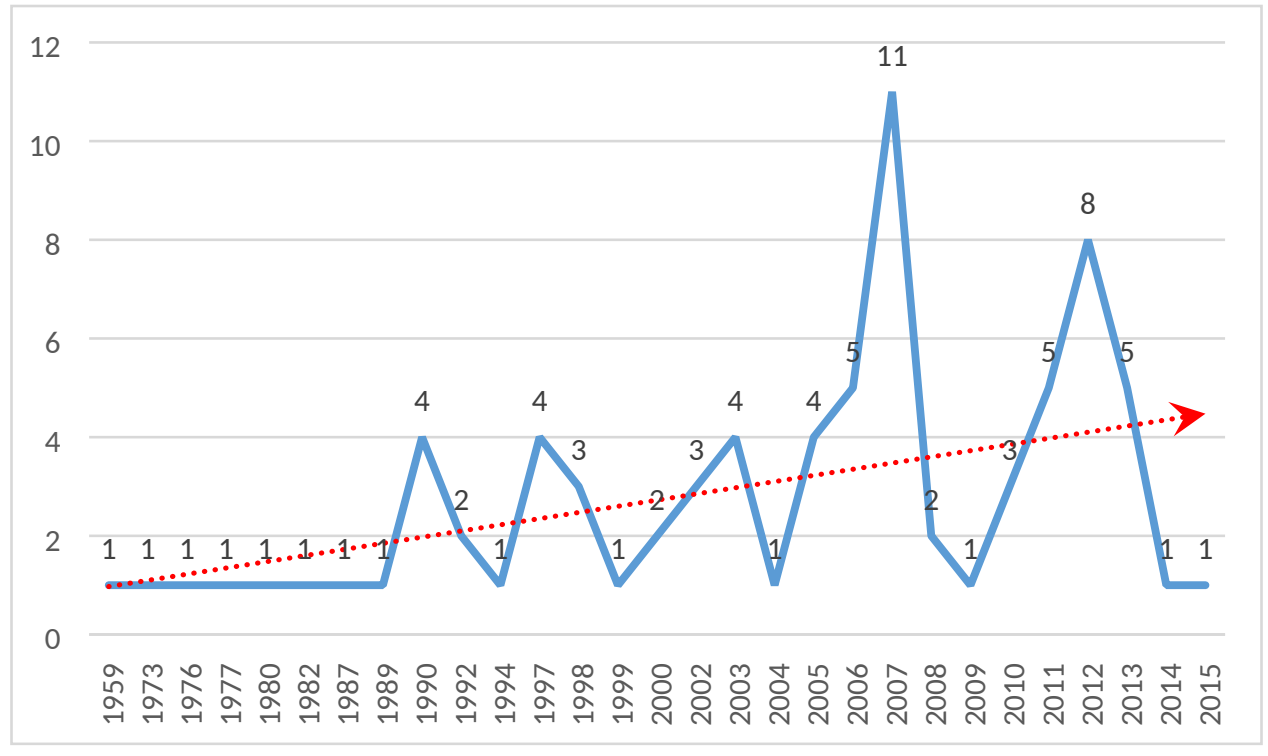

Figure 3- EDC beginning per Year in Central America According to the EJAtlas. Source: Authors based on EJAtlas (https://ejatlas.org/).

In Table 1, we can see that the metabolic sectors with the highest increase after 2002 are mining and water management. Water management conflicts also includes hydroelectric power generation aside water rights and sanitation disputes. The configuration of economic structures related to neo-extractivism demanding more raw materials and energy would seem a logical generator here. Biomass and land acquisition conflicts maintain a more or less constant rate since 1991 (slightly larger in the 1991-2001 decade). Since they include agriculture and cattle, they seem like the result of traditional extractivist activities too. Yet here one needs to take into account the role of "new" agricultural activities which have been expanded since the end of the last century (i.e. pineapples and African palm). Tourism recreation conflicts appear in the 1990s and increase in the new century. Similarly, infrastructure conflicts are a phenomenon of this century. The conflicts associated with these two last sectors are more correlated with the current development models of Costa Rica and Panama, more focused in the service sector. 
Table 1- EDC per Beginning Year and Metabolic Sector in Central America According to the EJAtlas. Source: Navas (2016) for the MESOCA-ANCA Project.

\begin{tabular}{|c|c|c|c|c|c|c|}
\hline \multirow[b]{2}{*}{ Metabolic Sector } & \multicolumn{5}{|c|}{ Number of Conflicts } & \multirow{2}{*}{$\begin{array}{c}\text { General } \\
\text { Total }\end{array}$} \\
\hline & $\begin{array}{c}\text { Before } \\
1990\end{array}$ & $\begin{array}{l}1991- \\
2001\end{array}$ & $\begin{array}{l}2002- \\
2010\end{array}$ & $\begin{array}{l}\text { After } \\
2010\end{array}$ & Unknown & \\
\hline \multicolumn{7}{|l|}{ Biomass and Land } \\
\hline Acquisition & 3 & 6 & 4 & 3 & 1 & 17 \\
\hline Biodiversity Conservation & 2 & 1 & & & & 3 \\
\hline Fossil Fuel Energy & 2 & 2 & & 2 & & 6 \\
\hline Water Management & 2 & 1 & 10 & 6 & & 19 \\
\hline Industry & & & & 1 & & 1 \\
\hline Infrastructure & & & 1 & 2 & & 3 \\
\hline Waste Management & & & & 1 & & 1 \\
\hline Mining & 2 & 4 & 12 & 5 & & 23 \\
\hline Tourism & & 2 & 4 & 1 & & 7 \\
\hline General Total & 11 & 16 & 31 & 21 & 1 & 80 \\
\hline
\end{tabular}

The intensity of the conflicts registered for each metabolic sector shows us that the conflicts related to biomass/land acquisition and mining are predominantly high in intensity (according to the EJAtlas scale). Of the three prevailing, water management conflicts have a high percentage in this category too, yet more are in the middle intensity range. Interestingly, the three conflicts of biodiversity conservation registered are all of high intensity (Table 2). Being these categories all related to territorial control may be an explanation for this trend in a region known for land tenure insecurity and lack of recognition of indigenous land rights. This high intensity has frequently resulted human life loss.

This sad fact is illustrated by the revelations of Global Witness in its 2016 report "In Dangerous Ground", dedicated to the deceased Honduran environmental activist Berta Cáceres. The report assures that 2015 was the year with the largest amount of deaths of environmental defenders throughout the world in record: a total 185. Latin America registered 66\% of these deaths: Brasil 50), Colombia (26), Perú (12), Nicaragua (12), Guatemala (10), Honduras (8) and México (4) for a total of 122 (Global Witness, 2016).

Unfortunately the effects of EDCs are not evenly distributed in the region as, according to the figures synthesized from the EJAtlas, the main groups affected are Indigenous and peasant communities living in rural areas (Figure 4). These areas also have the lowest levels of social development in Central America as elsewhere in the world (Aguilar-González, 2016). 


\begin{tabular}{|c|c|c|c|c|c|}
\hline \multirow{2}{*}{ Metabolic Sector } & \multicolumn{4}{|c|}{ Intesity of Conflicts } & \multirow{2}{*}{ Total } \\
\hline & Low & Medium & High & Unknown & \\
\hline $\begin{array}{l}\text { Biomass and Land } \\
\text { Acquisition }\end{array}$ & 2 & 6 & 9 & & 17 \\
\hline Biodiversity Conservation & & & 3 & & 3 \\
\hline Fossil Energy /CJ & 2 & 2 & 1 & 1 & 6 \\
\hline Water Management & & 10 & 9 & & 19 \\
\hline Industry & & 1 & & & 1 \\
\hline Infrastructure & & 3 & & & 3 \\
\hline Waste Management & & 1 & & & 1 \\
\hline Mining & 1 & 9 & 13 & & 23 \\
\hline Tourism & 3 & 3 & 1 & & 7 \\
\hline General Total & 8 & 35 & 36 & 1 & 80 \\
\hline
\end{tabular}

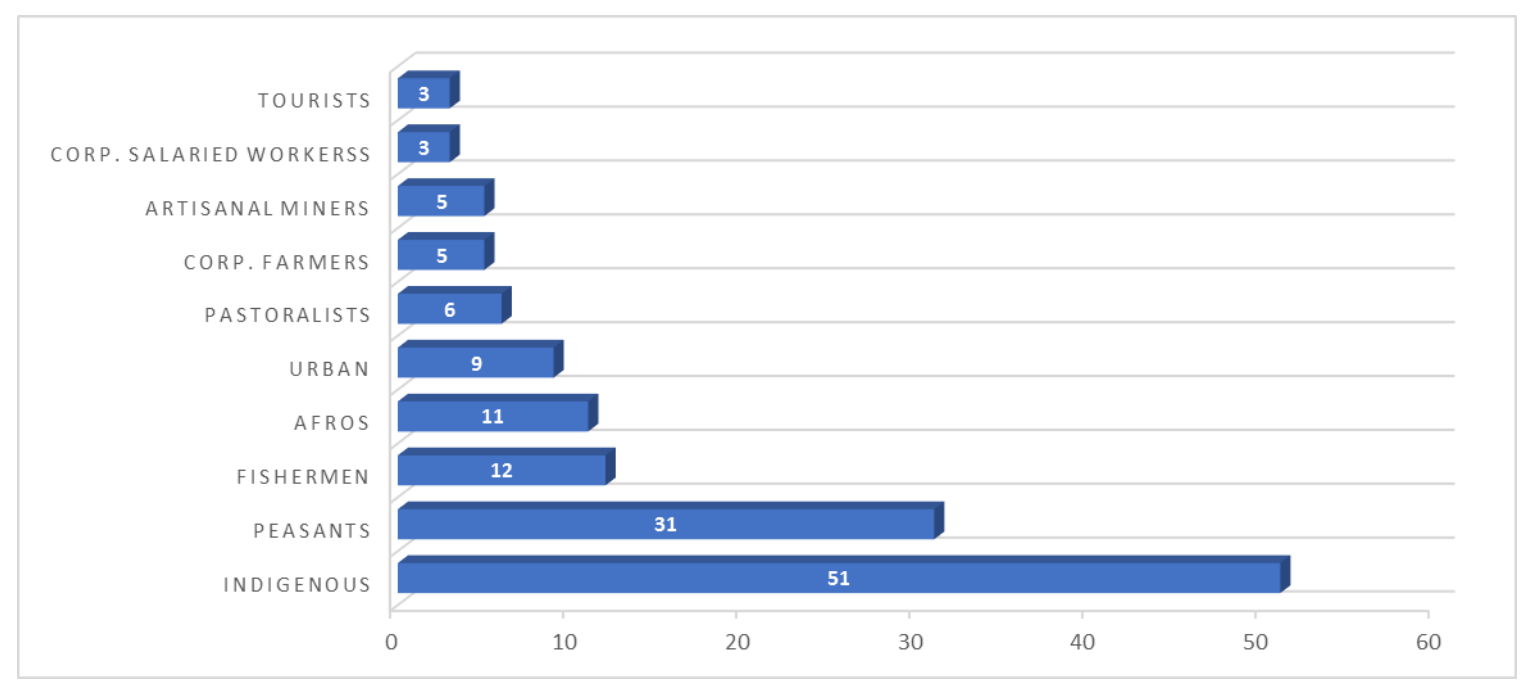

Figure 4- Groups Affected by EDC in Central America. Source: Adapted from Navas (2016) from MESOCA-ANCA Project. 
The EJAtlas also shows us a trend which is basic to understand the diverse roles that the State plays in Central America. Costa Rica and El Salvador show the highest rates of what the Atlas calls environmental justice successes. These are cases where projects have been stopped from happening. In these countries courts have declared mining projects illegal and both have banned open pit mining largely due to the action of civil society organizations. A combination of regulation enforcement by courts and civil society actions have shown the potential role that conflicts can play in leading legal reforms that may alter structural conditions that have facilitated the development of extractive activities in Central America (Alemancia, et al., 2015). We will evaluate these trends next in view of the Guatemalan experience.

Table 2- Environmental Justice Successes as of 2015 Relative to Number of Conflicts According to the EJAtlas. Source: Navas (2016) for MESOCA-ANCA Project

\begin{tabular}{|lrrrr|}
\hline Country & $\begin{array}{r}\text { Number of EJ } \\
\text { Successes }\end{array}$ & Number of Conflicts & Rate of Success \\
\hline Guatemala & 6 & 22 & $27 \%$ \\
\hline Belice & 1 & 3 & $33 \%$ \\
\hline Honduras & 1 & $15^{2}$ & $7 \%$ \\
\hline El Salvador & 3 & $7^{2}$ & $43 \%$ \\
\hline Nicaragua & 1 & $9^{2}$ & $11 \%$ \\
\hline Costa Rica & 7 & 11 & $64 \%$ \\
\hline Panamá & 1 & 15 & $7 \%$ \\
\hline
\end{tabular}

\subsection{The Socio-Historical Evolution of Mining in Guatemala and the Emergence of Nested Ecological Distribution Conflicts.}

Guatemala has one of the highest inequality levels in Latin America and the Caribbean. Its Gini index for income inequality is reported to be 0.531 in 2015, indicating a relatively high level of disparity between those sectors with the highest and lower levels of income in the nation ${ }^{3}$ (UNDP,

\footnotetext{
${ }^{2}$ The registry includes a conflict in the Gulf of Fonseca which is shared by Honduras, El Salvador and Nicaragua.

${ }^{3}$ The Gini Index is a measure of statistical dispersion which ranges from 0 to 1 and is used for measuring the disparity in indicators such as land ownership, income, wealth and others. A measure of 0 indicates perfect equality, whereas a measure of 1 maximal inequality. Levels of 0.6 or above indicate an extremely high level of inequality. Currently, according to the World Bank, only four countries surpass this benchmark: South Africa, Namibia, Haiti and Bostwana. Guatemala ranks as the $17^{\text {th }}$ most unequal country in the World Bank database according to the last year reported of the Gini Index for income. The data can be accessed at http://api.worldbank.org/v2/en/indicator/SI.POV.GINI?downloadformat=xml.
} 
2016). According to the Latinobarómetro Report of 2011, Guatemala is the country with the highest perception of discrimination in Latin America. More than half of Guatemalans (51\%) believe that they are discriminated based on race (Corporación Latinobarómetro, 2011). The abuse against human rights, the fragility of the social fabric, the heritage of more than thirty years of armed conflict, acts of genocide and the irresolute situation of land ownership between the State, rural and indigenous territories, and the private sector all combine too to create an environment that is prone to the development of conflicts in different realms (IRALEP, 2010; Maas, et al., 2014; UNDP, 2016). These factors have been enhanced by the pressure exercised by extractive activities promoted as part of the model of development by Guatemalan governments now for many decades. A marked mistrust towards public institutions has its roots in this conflictive landscape (Maas, et al., 2014).

Therefore, several studies concur today that the conflictivity in mining activities is framed within the wider context of social protest, inequity, mistrust of the State and of opposing visions of development for the country and for its communities (Castagnino, 2006; van de Sandt, 2009; Araya, et al., 2010; IRALEP, 2010; IARNA-URL, 2012; Waxenecker, 2013; ICEFI, 2014; Aldana \& Abate, 2016; Shipton, 2017). Guatemalan mining has evolved historically in parallel to the transformation of its social metabolism and the unfair appropriation of environmental space by the Spanish, ladino oligarchies, and later by transnational-local economic groups which concentrate power and wealth.

It started in colonial times, with the exploitation of silver, gold and lead (Waxenecker, 2013). With the independence in 1821, mining activity decreased due the instability generated by the clashes within independence movements. In 1871, with the Liberal Reform, mining in Guatemala began to depend on the price of metals in the international market. Yet, it was not until halfway through the 20th century when the extraction of metals (especially gold and silver) caused an acceleration of the social metabolism. After the coup of 1954, the systematic adoption of policies for mining extraction (such as a Law of Quarries, two laws for the promotion of small mining and two mining laws) signals a special emphasis on the tendency of the Guatemalan State to promote the interests of mining companies (Solano, 2005; Castagnino, 2006; UNDP, 2016).

In this context, the case of the EXMIBAL project (Fénix-El Estor) is emblematic of the overlap in interests between transnational companies and the political and economic elites of the country. After the approval of the new Code of Mining Extraction of 1965, INCO (International Nickel 
Company from Canada) was awarded 410 square kilometers of concessions in the departments of Alta Verapaz and Izabal for a period of 40 years, making this company one of the biggest landowners of the regions (which already had serious land tenure and indigenous rights recognition issues). The rejection of mining activities became an opposition to the general social situation in the country and the power of those who controlled it. The repression against the opposition of mining projects mixed with the repression against insurgent groups. This repression included the Massacre of Panzós in 1978 and generated significant international and national protests (Grandin, 2004; Castagnino, 2006; Nolin \& Stephens, 2010; UNDP, 2016).

Guatemala started then showing examples of nested ecological distribution conflicts in the mining sector. A nested ecological distribution conflict (NEDC) is an EDC that cannot be understood in an isolated manner as it is deeply nested in the background of inequality and violence of the studied reality. The recognition of this substrate requires the understanding of the interaction and superposition between the general social conflictivity and the EDC. This interrelation between the scales of conflictivity generates higher complexity with regarding the identification of the actors and the interests that are manifested in the conflicts. Additionally, the multiplicity of actors and of spaces of conflictivity increases the potential of the emerging complexity, making the outcomes of the EDC more unpredictable and the potential socio-ecological costs higher (Aguilar-González, et al., 2015; UNDP, 2016).

In 1982 INCO decided to close their activities, in part because of the increase in gas prices and the decrease in the price of nickel in international markets. Some analysts think that other motives were behind this decision (Solano, 2005; UNDP, 2016).

After the signing of the Peace Accords in 1996, globalization and free market proposals, with an increase in transnational private investment become the dominant political trend in Guatemala. The granting of mining licenses, particularly for metals, is increased during the Arzú and Berger governments, as we will also show later in the results (UNDP, 2016).

The process of "liberalization" is accentuated by the signing of free trade agreements between Central America and the Dominican Republic with the United States (DR-CAFTA) in 2004. A significant surge in mining activities is favored by the increased focus on export products, the rising of the price of minerals in international markets, as well as innovative technology that allowed an expansion of mining activities with higher profitability (IARNA-URL, 2012; UNDP, 2016). 
The above mentioned increase in mining licenses brings a novel reaction that marks the main trend in opposition in the last decades (UNDP, 2016). In 2003 an exploitation license for gold, silver, zinc, lead, iron, copper and mercury was granted to the transnational Glamis Gold Ltd in the department of San Marcos as "Proyecto Mina Marlin". Glamis Gold is the owner of the Guatemalan subsidirary Montana Exploradora Guatemalteca S.A. The inhabitants of Sipakapa and San Miguel de Ixtahuacan (largely Maya-Quiche, Sipakapense and Maya Mam) and environmental organizations manifested their rejection to the mine. They were concerned about the environmental impact, the lack of popular participation from the communities that surround the project and the violation of indigenous territories of collective property already protected by international legislation. In the spirit of International Labor Organization's Convention 169 (ratified by Guatemala in 1996), on June $18^{\text {th }}, 2005$, the first self-organized community consultation about the acceptance or rejection of the mining project in their lands takes place in Sipakapa. Thirteen communities participated. The results were 2,448 votes against the mine, 35 in favor, 8 null, and 1 left blank (van de Sandt, 2009; Yagenova \& García, 2009; Laplante \& Nolin, 2014).

The beginning of operation of the Marlin Mine in 2005, marks another fundamental change in the scale of production of metallic mining in Guatemala. The mine evolves to produce $96 \%$ in all mining sales in the country between 2005 and 2011 (IARNA-URL, 2012; UNDP, 2016). The operation of this project also generated an increase in the intensity and radicalization of the opposition by indigenous communities and civil society organizations to mining projects in Guatemala (Yagenova \& García, 2009; Nolin \& Stephens, 2010; Laplante \& Nolin, 2014).

During the specific period studied (2005-2013), the mining sector had a continuous productive expansion. The added value of this economic activity was reported in 2011 to be more than triple its original value in 2006 (ICEFI, 2014).

\subsection{Geographic and Temporal Trends in the Appropriation of Environmental Space by Mining Projects (2005-2013) in Guatemala.}

Figure 5, resulting from the analysis of the MEM database ratifies the trends above stated for the 2005-2013 period under scrutiny as Berger (2004-2008) and Perez Molina (2012-2015), to a lesser extent, maintained the trend of the Arzu (1998-2002) period of granting many licenses for exploration and exploitation per year. 


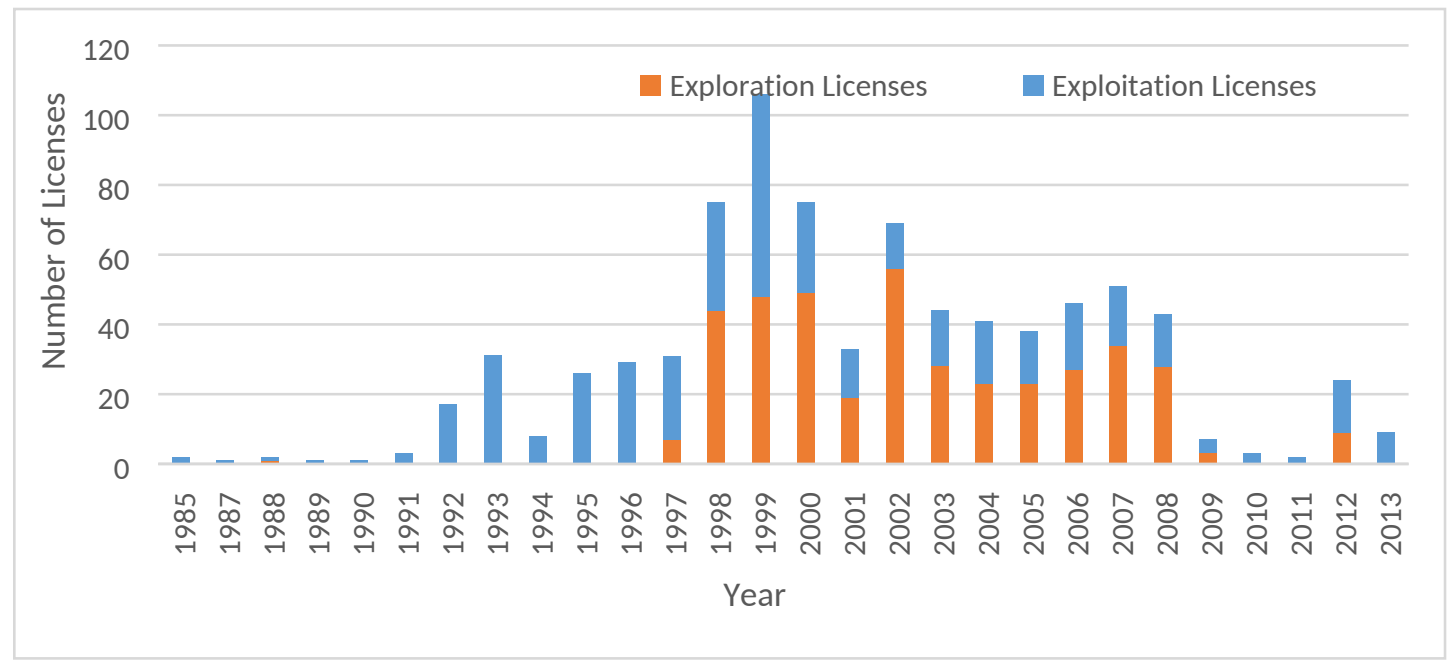

Figure 5-Exploration and Exploitation Mining Licenses 1985-2013. Source: Modified from Aguilar-González et al. (2015).

During the Alvaro Colom administration (2008-2012) the granting of licenses remained under a technical moratorium brought about by a resolution from the constitutional court to a claim presented by the NGO CALAS ${ }^{4}$ (UNDP, 2016). Of the exploration licenses given in the examined period the majority were for metallic mining. The majority of exploitation licenses were for nonmetallic mining or for construction materials.

Regarding geographical distribution, we obtained results for all types of mining jointly and differentiated (by mining types and exploitation and exploration rights). This distribution is related to the level of EDCs, as not all types of mining have generated the same levels of conflicts. It is the metallic mining sector that has generated highest levels of conflicts (Aguilar-González, et al., 2015).

In the case of metallic mining, the concentration of concessions of environmental space in active licenses (October 2013) was in departments with higher levels of indigenous population (with over 25\%) when it comes to exploration. As Figure 6 shows, the same situation prevails when exploitation permits are added.

${ }^{4}$ Centro de Acción Legal Ambiental y Social 


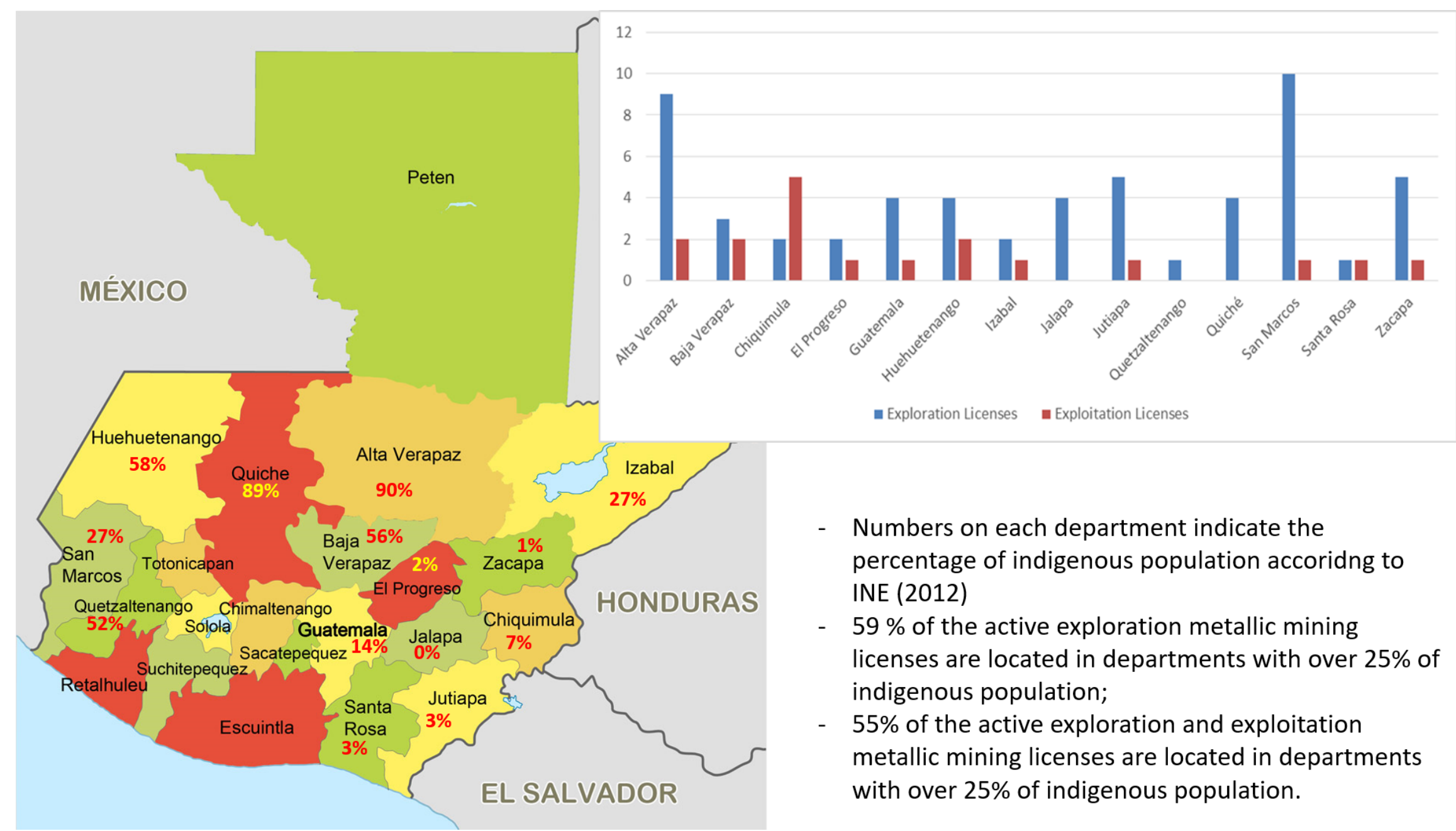

Figure 6- Active Licenses (October 2013) for the Exploration and Exploitation of Metallic Mining per Department in Guatemala and Percentage of Indigenous Population. Source: Modified from Aguilar-González et al. (2015). Data on indigenous population by department is from Instituto Nacional de Estadísticas (2012). 


\subsection{Characterization of Relevant EDCs and Effects of Mining Activity Documented}

Eleven conflicts were identified in this research as relevant examples to characterize conflictivity in Guatemala, some of them coinciding with the ones identified by OCMAL's database. They reported 208 mining conflicts in Latin America in 2015 of which six were located in Guatemala. The way in which OCMAL selects conflicts is different. They include a mixture of judicial, direct actions and projects.

PNUD later excluded from our database the ones that we classified at a latent stage for its Human Development Report, in order to only represent conflicts that have manifested in some form of action, even if at low intensity. We adopt this approach in this report in order to be consistent with their publication. As can be seen in Table 4, most EDCs identified have reached high intensity. The older ones are de-escalating after reaching that level of intensity, while three were reported as in crisis at the time of the study. Eighty percent of these conflicts are in metallic mining.

All conflicts in the escalation stage are of medium intensity and in the metallic mining sector. Seventy eight percent of the conflicts began after 2005. Eight of the conflicts are related with transnational capital, mostly Canadian.

For a more detailed analysis of each of these conflicts, the description is available in the final report to UNDP Guatemala (Aguilar, et al., 2015). We summarize here some other important trends. The conflicts can begin in different phases of a mining project. In some cases (Los Chocoyos or Cerro Blanco, amongst others), resistance and actions against mining were carried out in phases previous to the start of the activity. In other cases (La Puya, Marlin, Cementos Progreso) communities act during the construction or extraction of mineral and there are confrontations on site with high indices of violence.

Martínez-Alier holds that this conflictivity is sparked by a clash of perceptions and interests about what is interpreted as development, but, most of all, over the distribution of environmental costs and economic benefits of each activity (Martínez-Alier, et al., 2010). The most vulnerable and economically impoverished populations (mestizo rural communities, peasants, indigenous territories) are the most impacted by the negative effects of mining activities. This resistance movement for environmental justice has also been called "Environmentalism of the Poor" (Martínez-Alier, 2003). 
Table 3- EDCs identified as the Most Relevant for the Mining Sector in Guatemala. Source: Modified from Aguilar-González et al. (2015) and PNUD (2016).

\begin{tabular}{|c|c|c|c|c|c|c|}
\hline Name & Department & $\begin{array}{r}\text { Type/ Mineral } \\
\text { Extracted }\end{array}$ & $\begin{array}{r}\text { Year } \\
\text { Conflict } \\
\text { Began }\end{array}$ & $\begin{array}{l}\text { Intensity } \\
\text { of the } \\
\text { Conflict }\end{array}$ & $\begin{array}{r}\text { State of the } \\
\text { Conflict as of } \\
\text { the date of } \\
2015\end{array}$ & $\begin{array}{r}\text { Companies Involved and } \\
\text { Origin }\end{array}$ \\
\hline Fénix, Estor & $\begin{array}{r}\text { Izabal } \\
\text { Alta Verapaz }\end{array}$ & $\begin{array}{r}\text { Metallic } \\
\text { Nickel } \\
\text { Ferronickel }\end{array}$ & 1974 & $\begin{array}{r}\text { High } \\
\text { (includes } \\
\text { deaths } \\
\text { and rapes) }\end{array}$ & De-escalation & $\begin{array}{r}\text { INCO } \\
\text { HubBay Minerals (Canada) } \\
\text { Sky Resources (bought by } \\
\text { HubBay Resources-Canada) } \\
\text { Solway Investment (Russia) }\end{array}$ \\
\hline Marlin I & San Marcos & $\begin{array}{r}\text { Metallic } \\
\text { Gold } \\
\text { Silver }\end{array}$ & 2004 & $\begin{array}{r}\text { High } \\
\text { (includes } \\
\text { deaths- } \\
\text { wounded) }\end{array}$ & De-escalation & $\begin{array}{r}\text { GoldCorp (Canada) } \\
\text { Montana Exploradora } \\
\text { (Canada) }\end{array}$ \\
\hline $\begin{array}{l}\text { Cementos } \\
\text { Progreso }\end{array}$ & Guatemala & $\begin{array}{r}\text { Construction } \\
\text { Materials } \\
\text { Sand } \\
\text { Gravel } \\
\text { Limestone }\end{array}$ & 2005 & $\begin{array}{r}\text { High } \\
\text { (includes } \\
\text { deaths) }\end{array}$ & Crisis & $\begin{array}{r}\text { Cementos Progreso } \\
\text { (Guatemala) }\end{array}$ \\
\hline Cerro Blanco & Jutiapa & $\begin{array}{r}\text { Metallic } \\
\text { Gold }\end{array}$ & 2007 & Medium & De-escalation & GoldCorp (Canada) \\
\hline $\begin{array}{l}\text { Saturno II } \\
\text { San Rafael II } \\
\text { San Rafael III }\end{array}$ & Huehuetenango & $\begin{array}{r}\text { Metallic } \\
\text { Gold } \\
\text { Silver }\end{array}$ & 2011 & Medium & Escalation & $\begin{array}{r}\text { GoldCorp (Canada) } \\
\text { Montana Exploradora } \\
\text { (Canada) }\end{array}$ \\
\hline $\begin{array}{l}\text { La Puya } \\
\text { El Tambor - } \\
\text { VII Derivada }\end{array}$ & Guatemala & $\begin{array}{r}\text { Metallic } \\
\text { Gold } \\
\text { Silver }\end{array}$ & 2011 & High & Crisis & $\begin{array}{r}\text { Radius Gold Inc. (Canadá), } \\
\text { KCA (Kappes, Cassiday and } \\
\text { Associates) (USA), } \\
\text { EXMINGUA subsidiary of } \\
\text { KCA }\end{array}$ \\
\hline $\begin{array}{l}\text { Illegal Jade } \\
\text { Mining }\end{array}$ & Zacapa & $\begin{array}{r}\text { Non-Metallic } \\
\text { Jade }\end{array}$ & 2012 & Low & Surging & $\begin{array}{r}\text { Unidentified-several } \\
\text { Chinese capital companies }\end{array}$ \\
\hline Los Chocoyos & San Marcos & $\begin{array}{r}\text { Metallic } \\
\text { Gold } \\
\text { Silver }\end{array}$ & 2012 & Medium & Escalation & GoldCorp (Canada) \\
\hline $\begin{array}{l}\text { San Rafael } \\
\text { Escobal-Oasis }\end{array}$ & $\begin{array}{r}\text { Santa Rosa } \\
\text { Jalapa }\end{array}$ & $\begin{array}{r}\text { Metallic } \\
\text { Silver } \\
\text { Gold } \\
\text { Lead } \\
\text { Zinc }\end{array}$ & 2013 & $\begin{array}{r}\text { High } \\
\text { (includes } \\
\text { deaths- } \\
\text { wounded) }\end{array}$ & Crisis & $\begin{array}{r}\text { Tahoe Resources Inc } \\
\text { (Canada) }\end{array}$ \\
\hline
\end{tabular}

Before detailing some of the trends of the economic, social and environmental impacts documented, we clarify three particularities on the environmental impacts of mining: 1) they can be cumulative (like the contamination of a river with cyanide), 2) sometimes they are only identifiable on the long-run (for example, with health issues affecting local populations) and 3) the perception of damage may be ambiguous as it may be possible to identify a direct zone of impact but difficult to identify a zone impacted indirectly (Aguilar-González, et al., 2015). 
Table 5 synthesizes the impacts documented in the study. The following sections detail some important features of these impacts. The table presents positive and negative impacts on the economic, social and environmental dimensions. It includes an additional category which we call polysemic ${ }^{5}$ as we detected that its perception depends on the position of the diverse actors. The following subsections summarize some of the aspects we believe should be highlighted from this information.

Table 4 - Summary of Economic, Social and Environmental Impacts Documented in the EDCs identified as relevant. Source: Adapted from Aguilar, et al. (2015)

\begin{tabular}{|c|c|c|}
\hline Economic & Social & Environmental \\
\hline Positive Impacts & Positive Impacts & Positive Impacts \\
\hline $\begin{array}{l}\text { - } \text { Direct and indirect } \\
\text { employment creation } \\
\text { - Export revenue } \\
\text { - Corporate Social } \\
\text { Responsibility (CSR) } \\
\text { programs } \\
\text { - Fees and taxes to benefit } \\
\text { local economy } \\
\text { - Infrastructure }\end{array}$ & $\begin{array}{l}\text { CSR programs related to } \\
\text { health, education, etc. }\end{array}$ & $\begin{array}{l}\text { - } \text { Reforestation programs } \\
\text { - Investment in recycling } \\
\text { and environmental } \\
\text { education programs }\end{array}$ \\
\hline Negative Impacts & Negative Impacts & $\underline{\text { Negative Impacts }}$ \\
\hline $\begin{array}{l}\text { - } \text { Land monopolized } \\
\text { - Food insecurity increases } \\
\text { food costs in project } \\
\text { regions } \\
\text { - Economic losses to local } \\
\text { producers whose crops } \\
\text { are damaged by soil and } \\
\text { water pollution } \\
\text { - Tax exemptions and } \\
\text { incentives reduce tax base } \\
\text { in municipalities }\end{array}$ & $\begin{array}{l}\text { - } \text { Deaths-wounded } \\
\text { - } \text { Chironmental injustice } \\
\text { and loss of ancestral } \\
\text { knowledge } \\
\text { - } \text { Demographic } \\
\text { transformation by } \\
\text { migration movements } \\
\text { - Forced displacements } \\
\text { - Community divisions } \\
\text { - Increase in criminality, } \\
\text { drug addiction, alcoholism } \\
\text { and other social problems } \\
\text { - Destruction of } \\
\text { archeological legacy } \\
\text { - Human health impacts } \\
\text { - Militarization and increase } \\
\text { in police presence } \\
\text { - Human rights violations- } \\
\text { criminalization of protest }\end{array}$ & $\begin{array}{l}\text { - } \text { Loss of biodiversity } \\
\text { - } \text { Deforestation } \\
\text { - } \text { Air pollution (particulates) } \\
\text { - Sound pollution } \\
\text { (machinery) } \\
\text { - Water pollution } \\
\text { (superficial and } \\
\text { underground) } \\
\text { - Soil pollution } \\
\text { - Reduction in } \\
\text { hydrogeological } \\
\text { connectivity } \\
\text { - Increase in waste } \\
\text { generation (solid and } \\
\text { liquid) }\end{array}$ \\
\hline
\end{tabular}

\footnotetext{
${ }^{5}$ Polysemic refers to the idea that any text can have multiple meanings rather than a single meaning.
} 


\begin{tabular}{|c|c|c|}
\hline Economic & Social & Environmental \\
\hline & $\begin{array}{l}\text { - Indigenous rights } \\
\text { violations-Lack of } \\
\text { community consultations } \\
\text { - Violence against women }\end{array}$ & \\
\hline Polysemic Impacts & Polysemic Impacts & Polysemic Impacts \\
\hline - Land price speculation & - Cultural changes & - Aesthetic alteration \\
\hline
\end{tabular}

\subsubsection{Economic Impacts}

At a macro level, the overall contribution of the mining and quarries sector to the Guatemalan economy is expressed in the contribution to the GDP. ICEFI criticizes this contribution as very low. During the period studied it went from $0.61 \%$ in 2005 to $0.85 \%$ in 2014 (ICEFI, 2014). The main economic activities of the country: manufacturing industry and agriculture generate $17 \%$ and $13 \%$ respectively.

At the local level, the informants in this study representing the industry stated that many positive economic, social and environmental impacts come through Corporate Social Responsibility (CSR) programs. They include help to schools, investments in infrastructure, etc. Some informants criticize these actions as generating dependence on the companies and a privatization of public services that should be offered by the State or local governments. These actions are used to justify the occupation of environmental space. Additionally, CSR actions are criticized as granting the power to foreign companies to disproportionately influence decision-making at the local level and to cover up human rights violations (ICEFI, 2014; Laplante \& Nolin, 2014; Aguilar-González, et al., 2015).

\subsubsection{Social Impacts}

Deaths and wounded from the violence in these conflicts are the first and most striking social impact. Beyond the distribution of the social, economic or environmental benefits and costs of the activity there is a dispute for the appropriation of environmental space.

This "territory" is conceived by conflicting actors from different perspectives: the indigenous and peasant populations defend their collective land titles because they are a space of social reproduction, of interaction with the land through agriculture, of defense, of history, of life. For the mining companies, this space is a zone where a mineral is extracted to obtain an economic 
benefit outside or within Guatemala. Therefore, the rural and indigenous nature of the zones where there is a larger concentration of the projects configures an impact of environmental injustice in a country where the highest indices of development are located in urban zones (Aguilar-González, et al., 2015).

From the perspective of human rights, a relevant trend that needs to be highlighted from the documented EDCs is the claim of the lack of free, prior and informed consultations (FPIC) that, by international law, redeem the rights of indigenous populations. This claim is accompanied by claims of scarce information available that local populations receive about the projects and their environmental, social and economic impacts. In response to this, as was discussed earlier and will be analyzed later, there have been community consultations organized by the communities themselves carried out on a national scale (Willems, 2009; Aguilar, et al., 2015).

Another social impact that was consistently found is the creation of strong divisions in terms of support for or rejection of the mining projects in the communities involved. These divisions lead to social fragmentation, a rupture of community networks and, most of all, to direct confrontations that lead to casualties such as in the Escobal, Marlin \& Fénix mining projects (Laplante \& Nolin, 2014; Aguilar-González, et al., 2015; UNDP, 2016).

The criminalization of social protest was also identified as a social impact. Along the same lines, threats, murder attempts and murders of those who oppose mining projects. This type of impact is currently a constant in Latin America being reported by OCMAL, by means of a map of criminalization for the opposition to mining activities and by Global Witness in its reports of murdered environmentalists. OCMAI registers 141 cases of criminalization of social protest in Latin America since 2003. Of them, 9 are located in Guatemala which include shootings, aggressions and other actions against activists ${ }^{6}$. As we pointed above, Global Witness reported in 2016 that 2015 was the year with the highest number of deaths of environmentalists in record with a total 185 deaths worldwide of which 66\% were in Latin America (122). Guatemala registered 10 deaths in different environmental conflicts. (Aguilar-González, et al., 2015; Global Witness, 2016).

Another social impact documented in conflicts with greater intensity is the forced displacement by the State with the help of the Guatemalan army, police and companies' security forces, leading to

\footnotetext{
${ }^{6}$ The OCMAL database and map can be found at https://mapa.conflictosmineros.net/ocmal_db-v2/
} 
high indices of violence, violations of human rights and the emotional tranquility of the communities. In order to maintain order and pacify the confrontations, the government militarizes the territory (Aguilar-González, et al., 2015).

Also the competition for territory includes vital elements like potable water. The pollution through chemicals and toxins like cyanide and mercury lead to the contamination of subterranean and superficial water sources. These generate health impacts and an unequal distribution of social risk and uncertainty. The surrounding communities of a mining project can show negative impacts in their public health in the long run, as can be seen in the cases of Marlin I in San Miguel Ixtahuacan (Shipton, 2017; Caxaj, et al., 2013; Caxaj, et al., 2014; Aguilar-González, et al., 2015; UNDP, 2016).

\subsubsection{Environmental Impacts}

The pollution of water, air, soil, deforestation, etc. were clearly identified environmental impacts that according to informants and the literature reviewed affect the project and surrounding territories. This information also identifies examples of how these negative impacts are cumulative. The deforestation for the construction of a mining project leads to the loss of biodiversity of flora and fauna, key elements to keep forming a policy of tourist attraction in Guatemala, which also would be reflected in the wellbeing of local actors and would have consequences in a whole economic sector of the country. The construction of roadways to bring in and take out machinery also interrupts ecological connectivity. These impacts are weaved with social ones also by way in which impacts such as the pollution of air for particular materials lead to health problems in community members. Additionally, the pollution of the soil in the mining project due to the use of chemicals affects not only the ecosystems but also the agricultural activities of its neighbors, causing a rupture of the local productive network (Castagnino, 2006; IARNA-URL, 2012; ICEFI, 2014; Maas, et al., 2014; Aguilar-González, et al., 2015; UNDP, 2016).

\subsection{Geographic Location of the Mining EDCs Studied}

Since 2010, IRALEP had highlighted metallic mining as having the highest amount of conflicts in the mining sector in Guatemala. Their analysis gathered data on municipalities showing conflicts related to mining at the time and compared it to the amount of metallic mining licenses (Table 6). 
They concluded that there was a high correlation between the number of licenses and mining conflicts (IRALEP, 2010). Their notion of conflict seems to be, in a similar fashion to other research institutes in Central America, more related to direct actions than to a conflict in the sense we use it here. Nevertheless, direct actions may be a reasonable indicator of conflicts. Their data, even if almost a decade old, is the best at the time and allows to understand the correlation of conflictivity with the surge in licenses that our data represents in the post conflict period in Guatemala.

Table 5- Metallic Mining Licenses and Conflict per Municipality in 2010. Source: Adapted from Aguilar, et al. (2015) - Modified from IRALEP (2010).

\begin{tabular}{r|ccc} 
Department & $\begin{array}{c}\text { Metallic Mining } \\
\text { Licenses }\end{array}$ & $\begin{array}{c}\text { Municipalities with metallic } \\
\text { mining conflicts between } \\
\text { Nov.2009-May 2010 }\end{array}$ & $\begin{array}{c}\text { Percentage of Municipalities } \\
\text { Reporting Conflicts }\end{array}$ \\
\hline $\begin{array}{r}\text { Izabal } \\
\text { San Marcos }\end{array}$ & 19 & 5 & 100 \\
Huehuetenango & 18 & 11 & 38 \\
Alta Verapaz & 15 & 29 & 94 \\
Baja Verapaz & 15 & 10 & 63 \\
Juliapa & 10 & 8 & 100 \\
Zacapa & 8 & 17 & 30 \\
Guatemala & 7 & 10 & 18 \\
Chiquimula & 6 & 17 & 55 \\
El Progreso & 6 & 11 & 38 \\
Quiché & 6 & 8 & 30 \\
Quetzaltenango & 4 & 21 & 13 \\
Jalapa & 4 & 24 & 71 \\
Totonicapán & 4 & 7 & 38 \\
Santa Rosa & 2 & 8 & 7 \\
Chimaltenango & 1 & 14 & 6 \\
Total & 0 & 16 & \\
\end{tabular}

As can be seen from placing the conflicts identified in this study on the map of mining rights presented in ICEFI (2014), the geographic distribution of the conflicts seems to be very influenced by the distribution of metallic mining licenses. The departments of San Marcos and Huehuetenango, with high indigenous populations, show a higher presence, somehow coinciding with the figures presented by IRALEP. The figures that IRALEP presents in Izabal may be interpreted as a reaction to a conflict of high intensity with a long history like that of El Estor. 


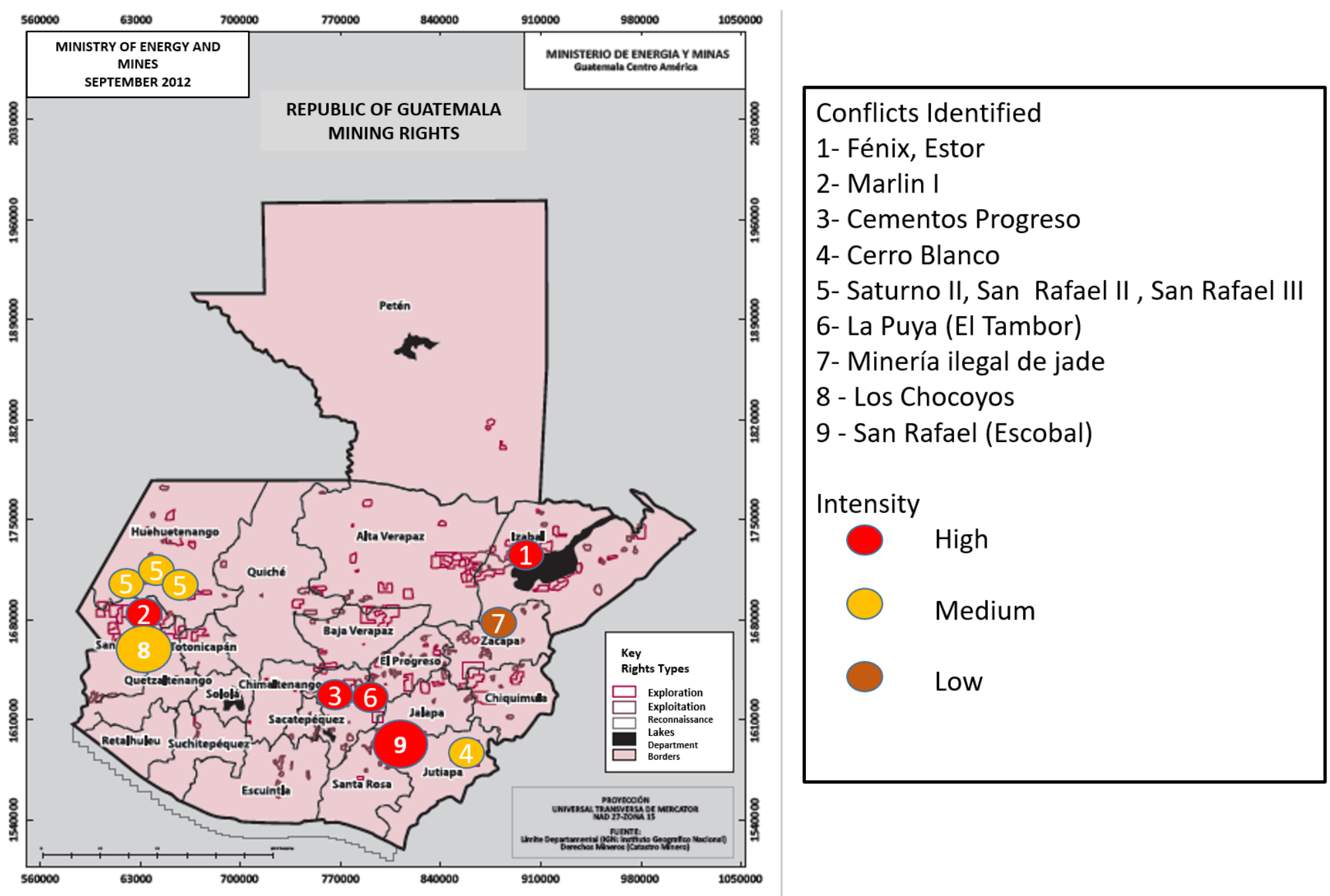

Figure 7- Mining EDCs Characterized and Geographic Distribution of Licenses. Source: Adapted from Aguilar, et al. (2015) based on Map in ICEFI (2014). 
In our view this spatial coincidence confirms that the general substrate of social conflictivity that underlies the land and indigenous rights problem in Guatemala is intertwined with the mining conflicts as for us to use the notion of nested conflictivity which we proposed above. The appropriation of environmental space may be overlapping with the lack of recognition of indigenous land rights and land concentration

\subsection{Social actors and mining EDCs.}

We first summarize the results of our discourse analysis grouping the actors in three main sectors: the State (Central Government and Local Government), mining companies and their supporting social/political elites and international financial institutions and civil society. Figure 8 shows a summary of the 3 sectors of actors and their support and conflict relationships.

The "State" sector is complex as it includes many diverse actors, whose actions and discourses don't necessarily agree. The perceptions of the different actor groups about it vary. The "insititutionality" of the State is considered by the private sector as weak. The fragility of its institutions leads to advances and setbacks when it comes to its extractive industry policy. For instance, in the view of this sector, on one side they try to provide incentives and try to protect the activity, yet they do not provide social services in the regions close to the mines, which contributes to social discontent. This generates uncertainty and instability when it comes to regulate the activities of the industries. Even though the State tends to establish a favorable climate for companies (which generate taxes, incomes, etc.), the mining companies claim from the State a more "clear" message (when it comes to successive moratoriums that are later lifted temporarilly, for example) and for clearer standards when it comes to evaluating the impacts of the activity. There is a consensus in the business sector about the necessity to have a rigorous technical framework, with standards better defined for matters such as environmental impact statements and institutions better prepared to evaluate them, for a new Mining Law (Orellana, 2015). 


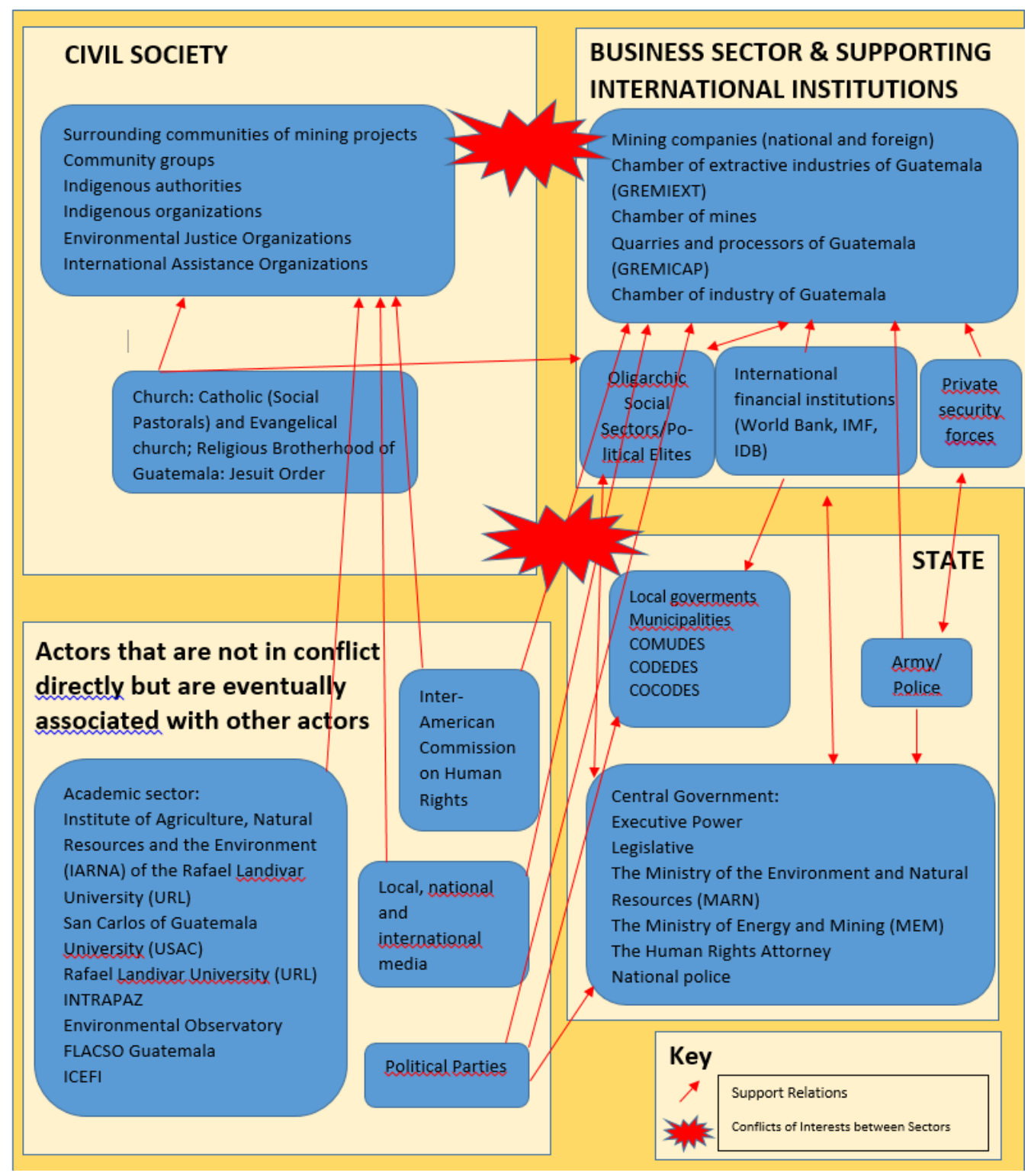

Figure 8 - Sectors Related to Mining Conflicts in Guatemala. Source: Adapted from Aguilar, et al. (2015).

The representatives from the central government themselves recognize that public institutions fail in their role to address mining conflicts and that weak institutions don't guarantee the fulfillment of the interest to cover the basic needs of the population. This discourse has evolved towards an awareness about the responsibility and the necessity of finding mechanisms of conflict resolution. In view of rising conflictivity in the last decade, the Ministry of Energy and Mines created a Viceministry of Social Development which, in 2012, was granted the human resources to create a Dialogue Unit with trained personnel (Quiñonez, et al., 2015). We gathered from our own 
observation during the interview that the notions of conflictivity that were used, the actions that were taken and the resources that the Viceministry had were very basic.

However, the reality of this discourse is very variable between public institutions and the interests at play. The Ministry of Environment and Natural Resources, for example, does not show an active role in the resolution of the conflicts and does not respond to its obligation to protect the environment against the development of extractive activities. Further, as a result of the collusion between public and private interests and in spite of certain advances such as the creation of public structures to handle conflict situations, the State often attempts to minimize the significance of protests and claims for a social and environmental justice. Similarly, it supports mining industries so that they may continue their activities (Maas, 2015; Molina, 2015). To delegitimize or criminalize protests, the central government tends to denounce "disinformation" by local actors, therefore attacking the credibility of social demands. Protestors are labeled as groups or organizations with "particular" interests and agendas that seek to influence citizens to generate opposition to mining projects. Equally, the State does not fully recognize the legitimacy of community consultations and seeks to regulate them. Even if they have been recognized as legally able to happen, they are yet to be legally binding (IRALEP, 2010; Oquelí, 2015; Rey Rosa, 2015).

With respect to the municipalities and decentralized public actors, their authority is characterized in many cases as symbolic. Many important decisions are still made by the central government. Municipalities do not promote local alternatives for development that would not be dependent on extractivism. In fact, they tend to favor CSR programs that substitute services like roads or other types of facilities that they are mandated to provide locally. In some exceptional cases municipalities have supported the communities and opposed mining, yet social actors claim that their opposition has been characterized as subversive (Maas, 2015; Molina, 2015; Rey Rosa, 2015).

When it comes to the mining sector, the ties between the mining activity and the model of development adopted after 1996 are important to understand actor perspectives about it. The promotion of extractive industries and the promotion of an economic development based on the extraction of natural resources are part of the process of free market promotion and neoextractivism that has characterized Guatemala's strategy of growth (Maas, 2015; Molina, 2015).

Governments as the one of Álvaro Arzú and Óscar Berger have claimed that mining activities have a strong positive impact in the economy of the country, generating economic and social development on a local as well as a national level. Studies by technical institutions such as ICEFI 
have shown that there is no evidence to substantiate this claim. (Molina, 2015) In the end, there is an antagonism between two visions of development represented by polarized actor groups: currently, there are a lot of movements that want to declare exclusive zones for indigenous populations and the presence of extractive industries do not fit in this model. This situation creates and contributes to the growing conflictivity (Maas, 2015; Molina, 2015).

Even in the mining sector recognizes that conflictivity is rooted in the structural characteristics of the Guatemalan society which lead to social inequality, they also claim there is some degree of manipulation of public opinion focused on increasing the perception of conflictivity. They argue that conflicts are worsened by the intervention of external organizations (NGOs, national or international, community leaders, etc.), which have their own agenda and organize campaigns of misinformation in the communities. They discredit the opposition to mining, suggesting that it serves electoral interests, local government interests in some cases, and for the NGOs to stay active receiving financial help from external sources (Monroy, et al., 2017).

Understanding power relations between public and private business actors is fundamental to understand the reasons for decisions on the management of national assets and political decisions. Social actors perceive business organizations and political/oligarchic elites as having a disproportionate amount of influence. Multilateral financial organisms such as the World Bank (WB), the Inter-American Bank of Development (IBD) are also important actors in creating political pressure to governments to support these kinds of businesses. Thus a series of power connections between international financial interests and local hegemonic groups are perceived at the root of social and institutional decisions in favor of mining projects (Maas, 2015; Molina, 2015).

Mining companies claim to have taken actions to try to reduce these conflicts and the resulting opposition. For the companies, the conflicts cause significant economic losses. For this, they assure that mining actors promote transparency practices from the industry. They consider that conflicts originate from insufficient information about the positive impacts and the benefits of mining activities (Marroquín, 2015; Monroy, et al., 2017; Orellana, 2015).

Additionally, mining companies state that they have developed CSR programs and strategies to face conflicts. Through these programs, the companies hope to improve the wellbeing in areas that are not directly involved in mining activities, with actions such as the financing of education, agroforestry projects, health and occupational training programs. This strategy is based on what they call a win-win vision: sustainable production and keeping social stability (Marroquín, 2015; 
Monroy, et al., 2017; Orellana, 2015). Companies have been strengthening their discourse and perfecting their strategies, adapting to each context. They seek the support of the communities, which legitimizes their presence in the project areas, generating empathy and presenting the industry as a fellow community member (Waxenecker, 2013).

As pointed before, a perceived negative consequence of this strategy is that it generates a sort of "privatization" of basic services, in the sense that the Company can define which the most important needs for the community are. Requests and claims go directly to the company, without passing by local public authorities as are the municipality or community councils. For that matter, there is a claim for a mayor intervention and clarity on behalf of the State, through Environmental Impact Studies and the regulation of the application of Convention 169 for the community consultations on the desirability of the projects. Opponents perceive that, situations of conflict occur in zones largely abandoned by the State for a long time, and the majority of demands on behalf of the population originate, apart from demands for economic opportunities, in deficiencies of State institutions (Maas, 2015; Molina, 2015).

The civil society sector is a mosaic of actors and organizations that do not necessarily have the same interests, nor do they act in the same territorial scale. They include the inhabitants of zones where mining projects are being developed and are those most affected. With their support, protest efforts have been organized to act in a coordinated way in the public sphere. Community organizations (including indigenous authorities) and national and international organizations come together into play (Maas, 2015; Molina, 2015). The sector has integrated into networks of solidarity that conform the regional opposition to the consequences of neoliberalism and, more specifically, neo-extractivism in Latin America (Holden \& Jacobson, 2008). The strategy of community mining consultations has come to be understood as a regional process diffused and transformed through anti-mining networks (Walter \& Urkidi, 2017). These networks have grown to be part of what is known as a global environmental justice movement (Martinez-Alier, et al., 2016).

On another set of interests, oligarchic social sectors usually support the position of private business and the status quo. The Catholic Church and other religious organizations frequently support the interests of community groups, NGOs, etc. Yet some conservative sectors support the interests of oligarchs (Maas, 2015; Molina, 2015). 
There is palpable concern among communities as well as civil society organizations relative to the negative impacts of this activity, a reaction to being the most immediate and disproportionate consequences of pollution to the environment, health risks, negative consequences for agriculture, restrictions to the access of ancestral land within indigenous territories, the imminent threat of the presence of security forces on mining sites, etc. The general perceived opinion among this sector holds that mining does not bring development or a positive impact to the communities. They argue that the benefits that mining yields do not compensate for the long-term damages that it causes. They demand means of mitigation to prevent derived environmental and social problems (Oquelí, 2015; Rey Rosa, 2015).

A heterogeneous sector that does not directly participate in the conflicts, yet supports actor groups playing many times a decisive role, includes academic institutions or research organizations. National and International media are also perceived as a key component of this group. The Inter-American Commission on Human Rights and political parties are recognized in this sector too (Maas, 2015; Rey Rosa, 2015).

According to a survey published in Prensa Libre in 2014 , $64 \%$ of a sample of Guatemalan society in the age range between 18 and 35 expressed to have an unfavorable view of mining projects (Álvarez, 2014). In general, the lack of information, of dialogue and of previous consultation before these projects begin is criticized. The perception is that neither are mining companies nor the government being transparent with respect to possible negative impacts. To denounce the criminalization of protest, many civil society actors highlight that conflicts are is positive in the sense that they promote an awakening of collective consciousness, strengthening social cohesion and promoting alternative solutions (Maas, 2015; Molina, 2015; Oquelí, 2015; Rey Rosa, 2015).

These sectors of civil society also condemn the role of a State that has been a promoter of extractive industries and not a regulator, by favoring and promoting the interests of this business sector (national and trasnational companies), through the creation and adoption of laws. The State places extractive industries in the center of its vision of development, dismissing the notions of value of indigenous peoples, and the demands of these groups in civil society, marginalizing communities from the consultation rights and decision making processes about the exploitation of the natural resources in their own territories (Oquelí, 2015; Rey Rosa, 2015). 
This mapping of actor interests and perceptions ratifies the idea of nested EDC. Beyond, it is important to understand the dynamics of these actor interactions through time to complete the framework of understanding of the EDC phenomena.

As stated above, a series of case studies of conflict action-response timelines were built for three of the identified conflicts: Fenix-El Estor, Marlin I and San Rafael, all high intensity metal mining conflicts. We chose as a sample for this paper, to present the case of Fénix-El Estor in Figure 9.

The figure represents the dynamic of pro and anti-mining actors through time in the period of interest. The amount and diversity of actions involved in these EDCs illustrates their complexity and their increase in intensity. The upper axis illustrates violent actions involved including deaths and human rights violations.

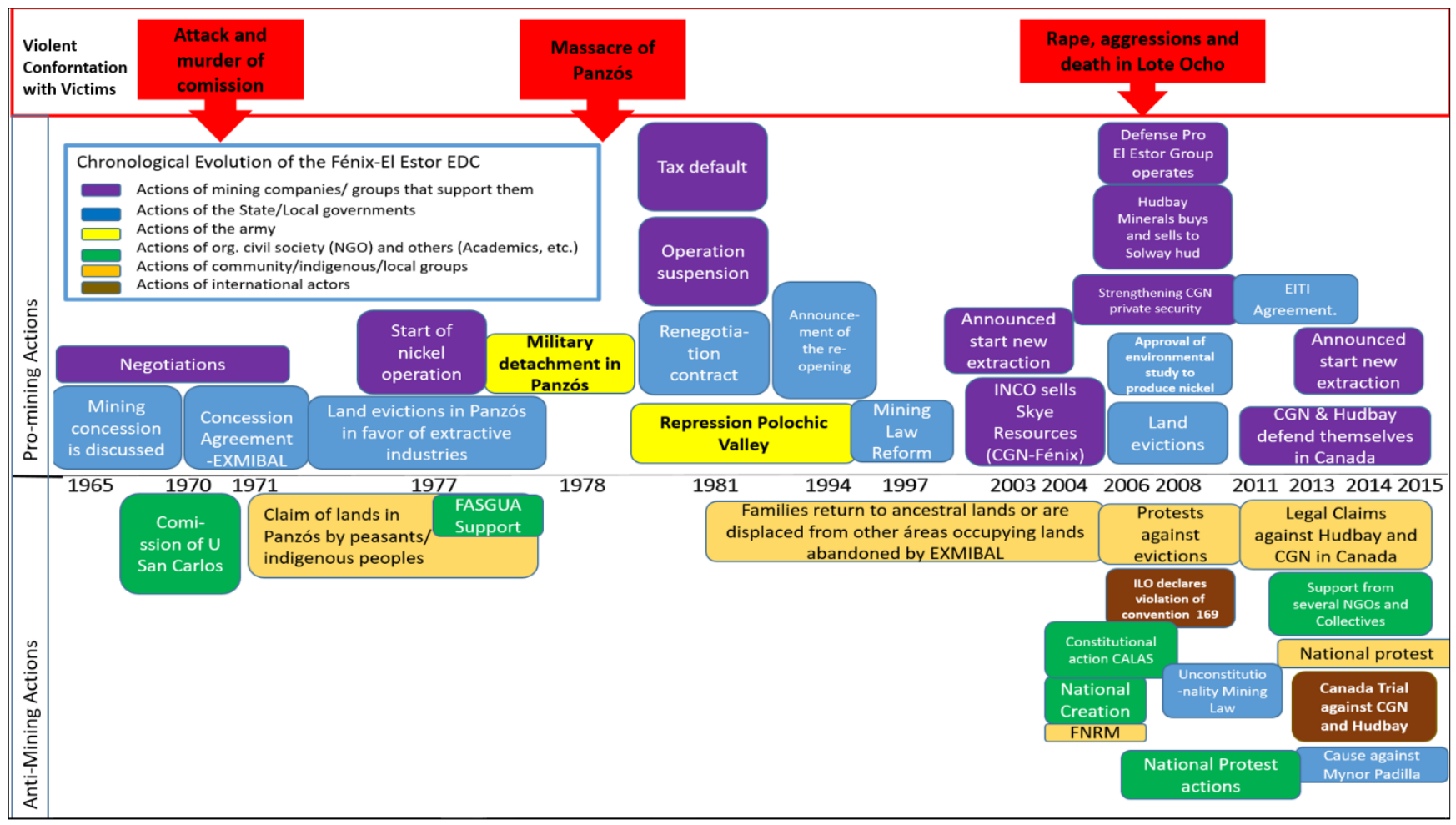

Figure 9- Action-Response Timeline of the Fénix-El Estor Mining EDC. Source: Adapted from Aguilar, et al. (2015)

These conflicts interact with one another around 2005, when among the anti-mining actions of organized civil society and others the creation of the FNRM (National Front of Resistance to Mining) is created. After this, the overlapping direct actions/protests against mining become a national reality in Guatemala. Illustrating this phenomena graphically, one could speak of swarms 
or spirals of mining EDC through time (Figure 10). This swarming has been definitely influenced by community consultations, led by multi-scalar social movements and local governments, becoming a contested emergent institution for participation (Walter \& Urkidi, 2017).

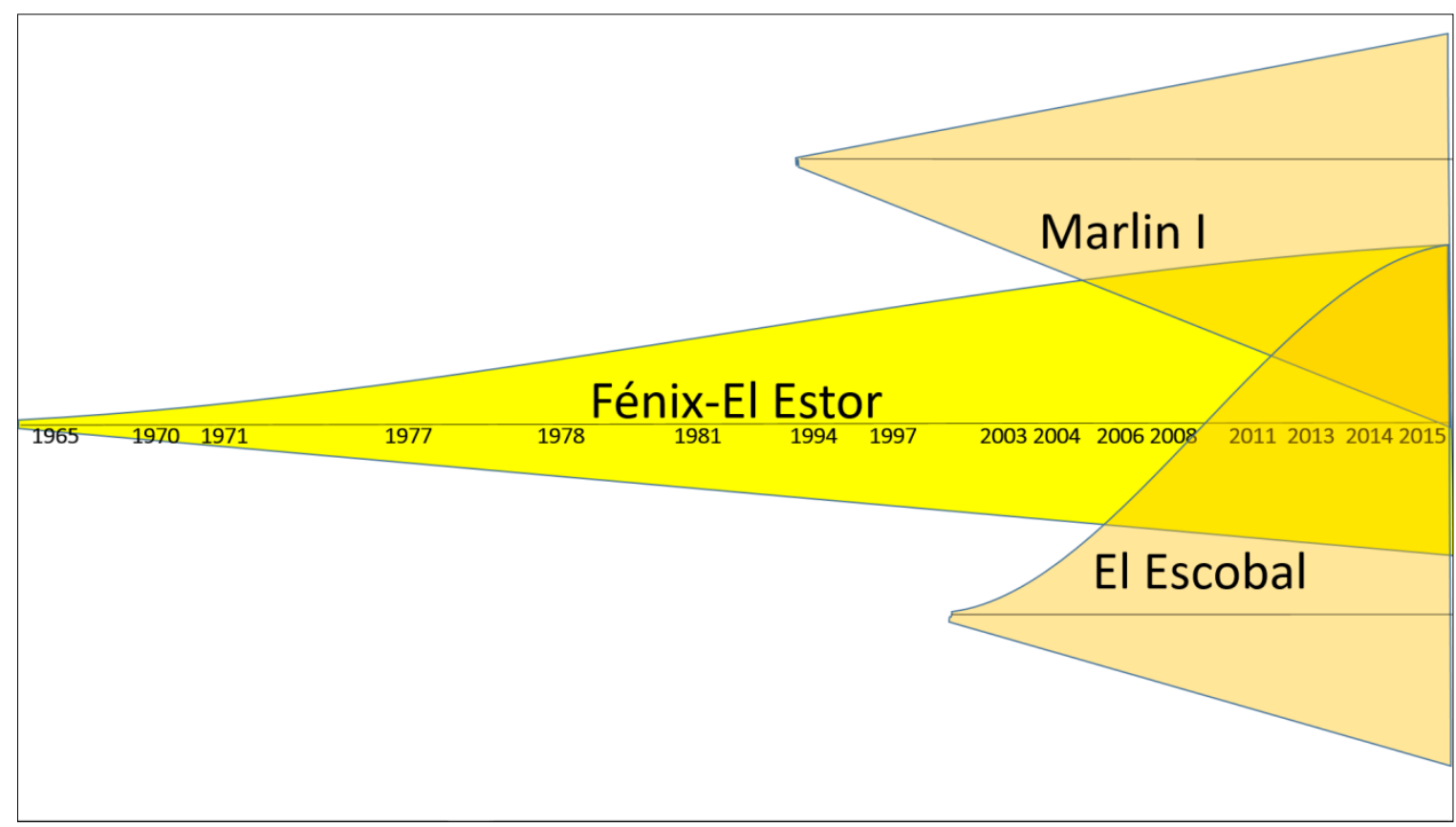

Figure 10- A Swarm or Spiral of Mining Conflicts Illustrated by the Overlap of Actions through Time after the Creation of the National Front against Mining in Guatemala. Source: Adapted from Aguilar et al. (2015)

These swarms or spiral of EDCs, characterized previously as a nested and complex within the Guatemalan substrate of socio-ecological injustice, confirm that the appropriate approach to address the problem of mining goes beyond managing individual conflicts. The escalation in the actions of the different actors that participate in them and their evolution through time, with potential multiplying effects, requires the development of appropriate social institutions to handle them.

3.7. The legal and institutional framework relative to mining and the role of the State in its implementation

Presently in Guatemala the legal regime of mining is formed by two main instruments. First, the Political Constitution of the Republic of Guatemala, in particular Article 125 which declares mining exploitation as an activity of public utility and necessity. Article 121 declares the property of the 
State in mining fields, therefore setting the framework for licenses or concessions to be needed in order to undertake this activity.

The second body is the Law of Mining, Decree 48-97 of the Congress of the Republic and its Rules of Procedure (Government Agreement 176-2001), reformed in a context of privatization and commercial liberalization. It establishes reconnaissance licenses, previous to the exploration phase. It also declares Areas of Mining Interest. Royalties for the State and Municipalities were reduced (from $6 \%$ to $1 \%$ ) and terms to resolve applications for licenses are reduced substantially (ICEFI, 2014; UNDP, 2016).

Additionally, the reform allowed foreign companies to acquire the total property of mining companies, being exempted, at the same time, from several tax payments. This leads to Guatemala's royalties and taxes being amongst the lowest in Latin America and the world (IRALEP, 2010).

However, in 2012, an agreement was signed between the Government of the Republic and the Chamber of Industry in Guatemala. This Agreement on the Implementation Framework of Voluntary Royalties Derived from Mining Activities in the Country, allows for companies to pay voluntary royalties, between $2 \%$ and $4 \%$ (plus the mandatory $1 \%$ ). With this agreement, royalties for the mining activity of non-precious metals increased from $1 \%$ to $3 \%$, while precious metals (gold and silver) were increased to 4\% (Molina, 2015).

Municipalities receive between $1.5 \%$ and $1.8 \%$ of these royalties, while the larger part goes to the common fund of the Central Government, in which there are no specific designations. Against this situation, there has been a discussion on the possibility of increasing mining royalties, which would mean modifying voluntary royalties and changes in the Mining Law. However, there has been no consensus reached so far (Molina, 2015).

The legal reform of 1997 is perceived as having facilitated and accelerated the concessions of licenses for the exploitation and exploration of metallic and non-metallic mining. Legal weaknesses (in environmental and fiscal matters) to develop mining activities have served as a perverse incentive aside this legislation to increase the social and environmental impacts of the activity. Since 2008 several moratoriums have been declared on the granting of new mining concessions, while there have been discussions on a New Mining Law within Congress. 
The Mining Law does not require that the indigenous people be consulted before the approval of exploration or exploitation licenses for mining projects. As said above, the rising opposition to mining activities and the protests against the lack of previous and informed consultation, has led to civil society organized community consultations to express their opinion (opposition) with respect to mining in their territories. Civil society organizations claim that these consultations have their legal support in ILO's Convention 169, ratified by Guatemala in 1996. By means of executive decree 9-96, it was transformed into a new internal legal norm. Also, Guatemala voted in favor of the adoption by the General Assembly of the United Nations of the Declaration of Rights of Indigenous Populations. However, there are no existing mechanisms in the current national legislation to guarantee the participation of the communities and the effective implementation of Convention 169 in mining activities and others. Therefore, especially the indigenous communities have developed their own processes to express their position about the projects that affect them. These are known as "community consultations of good faith", using the established methodology in the Municipal Code (Laplante \& Nolin, 2014; Maas, 2015; Walter \& Urkidi, 2017).

These consultations are labeled as controversial and discredited by the State, local public actors and mining companies, because of their methodologies as well as the validity of their decisions (Orellana, 2015). Yet, rulings have determined that they are indeed legal.

\section{Conclusion: Where to go? Institutional Reform and Mining Conflicts in Guatemala}

The Human Development Report from Guatemala (2015-2016) adopted a very suggestive name: "Beyond Conflict, Struggles for Wellbeing". In it, it focuses on the inequitable structural conditions of the Guatemalan reality, the historical process of the Peace Accords of the late XX Century, the potential of the country for human development, the lessons learned from social conflicts, land rights and distribution, mining conflicts, hydroelectric energy generation conflicts and the challenges of a democracy in construction (UNDP, 2016).

When we interviewed key academic/activist informants on the possibility of mining projects that would not generate conflicts, they reduced this possibility to 4 scenarios:

1. Mining projects are very low scale, have no surrounding population or their impacts are not known/have not been studied (Sastre I was presented as a case in point); 
2. There are projects but no organized civil society that would oppose, resist and develop collective actions that generate conflicts of diverse intensities;

3. Civil society is coopted and cannot oppose or organize a resistance;

4. The royalties are high since the first phase of exploration. This eases the will of communities from before and allows the establishment of power enclaves over the territory.

One of the most striking trends in these scenarios is that the informants never consider the role of the law or the institutions of the State, which they see as irrelevant due to their ineffectiveness. Obviously the intensity of the conflicts which involves deaths and human rights violations contributes greatly to the sense of distrust.

Significant structural changes are obviously needed in Guatemala in order for the country to be sustainable and fair. Beyond this, it is obvious that due to its history and impacts that open pit metallic mining is not a desirable activity for countries which seek sustainability and fairness. If, as is the perception of several social actors and has been a historical constant, the State is a supporter of this activity in Guatemala, the civil society and NGOs which organize to oppose it will have to continue expecting structural change to come as a result of swarms of conflicts. Human rights violations need to be stopped.

The depth of the conditions that place Guatemala at the top of registered conflicts in the Central American region makes it impossible for CSR programs to be able to buffer the effects of the prevailing situation. A shift in the power relations that control the State would be necessary to be able to implement the institutional changes that may lead to less confrontation due to the productive activities that characterize its model of development.

Those changes should include, but not be limited to, full implementation of Principle 10 of the Rio Convention meaning that the population needs to receive full access to information, participation in environmental governance decisions and full procedural rights in order to exercise the right to a healthy and clean environment. This is seen as an essential step in readiness to address global environmental problems today (particularly climate change) even by environmental outfits seen in the past as distant from participatory governance ideas such as USAID (ECOEDIT, 2016). 
In fact, the conflictive environment centered on mining is exacerbated by the lack of rigorous environmental legislation. This generates social protest and discontent over the way in which extractive industry activities develop in Guatemala.

Therefore, one of the fundamental conditions that is seen as necessary is to guarantee an adequate participatory environmental governance. It would serve as a framework for a fair distribution of the costs and benefits of the use of environmental space. Small weak offices specialized in documenting conflicts and a few public officers using alternative conflict resolution techniques will not suffice. An increase in the effectiveness and the social credibility in control, vigilance and adequate sustainable management mechanisms by those institutions in charge is essential. This includes increased resources for municipalities, protected area systems and the ministries in charge.

Finally, in visualizing the structural changes needed to establish a political and economic system that is socially, culturally and environmentally fair in Guatemala, a wider set of deep and important questions need to be asked and answered. These include what are the desirable features for a political and socio-economic system that can support environmental justice. Seeking to answer such questions goes beyond the bounds of this paper. Yet, it is good to know that the latest Human Development Report of the UNDP has sought to address them. The reader is invited to expand on this matter in this publication.

\section{Acknowledgements:}

This work was funded through a consultancy with the United Nations Development Program Office in Guatemala. Its results were used for the Human Development Report of Guatemala (20152016).

\section{References}

Aguilar González, B., 2013. Deuda ecológica y justicia ambiental: aplicaciones en América Latina y especificidades de Costa Rica. In: W. Pengue \& H. Feinstein, eds. Nuevos enfoques de la Economía Ecológica. Una perspectiva latinoamericana sobre el desarrollo. Buenos Aires: Lugar Editorial, pp. 254-294.

Aguilar González, B. et al., 2012. Valoración Económico-Ecológica Rápida de los Daños Ambientales Relacionados a los Cambios en la Cobertura del Suelo en la Fincas Propiedad de Industrias Infinito 
luego de la Resolución 244-2008-SCH del Área de Conservación Huetar Norte, San José, Costa Rica: Fundación Neotrópica, Editorial Heliconia.

Aguilar, G. B., Navas, G. \& Brun, C., 2015. Estudio sobre la conflictividad generada por proyectos de extracción minera en Guatemala, San José, Costa Rica: Fundación Neotrópica for UNDPGuatemala.

Aguilar-González, B., 2016. Justicia Ambiental en Costa Rica. Democracia Política, Económica, Ecológica y Conflictos Socio-ambientales, San José, Costa Rica: Fundación Friederich Ebert.

Aguilar-González, B., Navas, G. \& Brun, C., 2015. Estudio sobre la conflictividad generada por proyectos de extracción minera en Guatemala, Guatemala: PNUD.

Aldana, R. \& Abate, R., 2016. Banning Metal Mining in Guatemala. Vermont Law Review, Volume 40, pp. 596-671.

Alemancia, J. et al., 2015. El Extractivismo en América Central: Un Balance del Desarrollo de Las Industrias Extractivas, Panamá, Panamá: FES América Central.

Álvarez, C., 2014. Continúa fuerte rechazo a minería, según Encuesta. Prensa Libre, 20 enero, pp. http://www.prensalibre.com/noticias/comunitario/Continua-fuerte-rechazomineria_0_1069693059.html.

Araya, M. et al., 2010. Minería Metálica en Centroamérica, impactos y resistencia. In: G. Delgado, ed. Ecología Política de la Minería en América Latina. Aspectos socioeconómicos, legales y ambientales de la mega minerñia. México, D.F.: Universidad Nacional Autónoma de México, pp. 299-356.

Barriga, M., Campos, J., Corrales, O. \& Prins, C., 2007. Gobernanza ambiental, adaptativa y colaborativa en bosques modelo, cuencas hidrográficas y corredores biológicos Diez experiencias en cinco países latinoamericanos, Turrialba, Costa Rica: CATIE.

Bedoya, C. et al., 2010. Guía para la Transformación de Conflictos Socio-ambientales, Lima, Perú: Fondo para el Logro de los Objetivos del Milenio.

Brenner, L., 2010. Gobernanza ambiental, actores sociales y conflictos en las Áreas Protegidas Mexicanas. Revista Mexicana de Sociología, 72(2), pp. 283-310.

Castagnino, V., 2006. Minería de metales y derechos humanos en Guatemala. La mina Marlin en San Marcos, Guatemala: Brigadas de Paz Internacionales.

Caxaj, C., Berman, H., Ray, S. R. J. \& Varcoe, C., 2014. Strengths amidst vulnerabilities: the paradox of resistance in a mining-affected community in Guatemala.. Issues in mental health nursing, 35(11), pp. 824-834.

Caxaj, C. et al., 2013. Promises of Peace and Development Mining and Violence in Guatemala. Advances in nursing science, 36(3), pp. 213-228.

Corporación Latinobarómetro, 2011. Informe 2011, Santiago, Chile: Corporación Latinobarómetro. 
ECOEDIT, 2016. Central America Regional Environment and Climate Change Analysis. Final Regional and Tropical Forests and Biodiversity Analysis, Guatemala: USAID, Central America.

Global Witness, 2016. En Terreno Peligroso, London, UK: Global Witness.

Grandin, G., 2004. The last colonial massacre : Latin America in the Cold. Chicago: University of Chicago Press.

Heidelberg Institute for International Conflict Research, 2015. Conflict Barometer 2014, Heidelberg, Alemania: HIIK.

Hille, J., 1997. The Concept of Environmental Space, Luxembourg: European Environment Agency. Holden, W. \& Jacobson, R., 2008. Civil Society Opposition to Nonferrous Metals Mining in Guatemala. VOLUNTAS: International Journal of Voluntary and Nonprofit Organizations, 19(325), pp. https://doi.org/10.1007/s11266-008-9073-9.

IARNA-URL, 2012. Perfil Ambiental de Guatemala 2010-2012. Vulnerabilidad local y creciente construcción de riesgo, Guatemala, Guatemala: IARNA-URL (Instituto de Agricultura, Recursos Naturales y Ambiente de la Universidad Rafael Landívar).

ICEFI, 2014. La minerá en Guatemala: realidad y desafíos frente a la democracia y el desarrollo., Guatemala: Insituto Centroamericano de Estudios Fiscales.

IRALEP, 2010. Comprendiendo la conflictividad por minería en Guatemala para tender puentes de gobernabilidad, Guatemalla: Instituto Regional de Altos Estudios Políticos (IRALEP).

Laplante, J. \& Nolin, C., 2014. Consultas and Socially Responsible Investing in Guatemala: A Case Study Examining Maya Perspectives on the Indigenous Right to Free, Prior, and Informed Consent. Society \& Natural Resources: An International Journal, 27(3), pp. 231-248.

Maas, R., 2015. Researcher, IARNA - URL. Interview. [Interview] (24 March 2015).

Maas, R., Gálvez, J. \& Arrecis, M., 2014. Breve análisis de la conflictividad socioambiental de Guatemala. In: J. Gálvez \& C. Cleaves, eds. Compilación de investigaciones y análisis de coyuntura sobre la conflictividad socioambiental de Guatemala. Guatemala: IARNA-URL (Instituto de Agricultura, Recursos Naturales y Ambiente de la Universidad Rafael Landívar), pp. 2-27.

Marroquín, M., 2015. Executive Director, Goldcorp, Montana Exploradora. Interview [Interview] (26 March 2015).

Martínez-Alier, J., 2003. The Environmentalism of the Poor: A Study of Ecological Conflicts and Valuation. Cheltenham, UK: Edward Elgar.

Martínez-Alier, J., 2004. Los Conflictos Ecológico-Distributivos y los Indicadores de Sustentabilidad. Revista Iberoamericana de Economía Ecológica, Volume 1, pp. 21-30.

Martínez-Alier, J., 2008. Conflictos ecológicos y justicia ambiental. Papeles, Issue 103, pp. 11-27.

Martínez-Alier, J. et al., 2010. Social Metabolism, Ecological Distribution Conflicts, and Valuation Languages. Ecological Economics, 70(2), pp. 153-158. 
Martinez-Alier, J., Temper, L., Del Bene, D. \& A., S., 2016. Is there a global environmental justice movement? Journal of Peasant Studies, 3(731-755), p. 43.

Molina, L., 2015. Economist Rsearcher ICEFI (Instituto Centroamericano de Estudios Fiscales). Interview. [Interview] (25 March 2015).

Monroy, G., Retolaza, L. \& J., Z., 2017. Dirección de Sostenibilidad y Cumplimiento, Minera San Rafael. Interview [Interview] (27 March 2017).

Navas, G., 2016. Caracterización de la Conflictividad Socio-ambiental en América Central según el Atlas Mundial de Justicia Ambiental del proyecto EJOLT, San José, Costa Rica: Fundación Neotrópica Project Report.

Nolin, C. \& Stephens, J., 2010. "We Have to Protect the Investors": "Development" \& Canadian Mining Companies in Guatemala. Journal of Rural and Community Development, 5(3), pp. 37-70.

Oquelí, Y., 2015. Activist community of La Puya. Interview [Interview] (26 March 2015).

Orellana, M., 2015. President, Gremial de Industrias Extractivas GREMIEXT \& Operations Director of Cementos Progreso. Interview [Interview] (26 March 2015).

Osborn, A., 1963. Applied Imagination: Principles and Procedures of Creative Problem-Solving.. New York: Charles Scribner's Sons.

Paniagua, F., 2007. Caracterización de los Conflictos Socio-ambientales en Costa Rica: 2006 , San José, Costa Rica: Programa del Estado de la Nación.

Quiñonez, M., Reyes, O., Polanco, S. \& Chacón, J., 2015. Viceministerio de Desarrollo Sostenible, Interview [Interview] (24 March 2015).

Rey Rosa, M., 2015. Escuela de Pensamiento Ecologista Savia, founder of Fundación Defensores de la Naturaleza and Madre Selva. [Interview] (25 March 2015).

Sayago, S., 2014. El análisis del discurso como técnica de investigación cualitativa y cuantitativa en las ciencias sociales. Cinta moebio, Issue 49, pp. 1-10.

Shipton, L., 2017. Canada's Mining Industry in Guatemala and the Right to Health of Indigenous Peoples. Health and Human Rights Journal, Volume 8, pp.

https://www.hhrjournal.org/2017/08/canadas-mining-industry-in-guatemala-and-the-right-tohealth-of-indigenous-peoples/.

Solano, L., 2005. Guatemala: petróleo y minería en las entrañas del poder. Guatemala: Infopress Centroamericana.

Svampa, M., 2013. "Consenso de los Commodities" y lenguajes de valoración en América Latina. Nueva Sociedad, March-April, Issue 244, pp. 30-46.

Temper, L., del Bene, D., Argüelles, L. \& Çetinkaya, Y., 2015a. EJAtlas, mapeo colaborativo como herramienta para el monitoreo de la (in)justicia ambiental. Ecología Política, Volume 48, pp. 10-13.

Temper, L., Del Bene, D. \& Martinez-Alier, J., 2015b. Mapping the frontiers and front lines of global environmental justice: the EJAtlas. Journal of Political Ecology, Volume 22, pp. 255-278. 
Toledo, V., 2013. El metabolismo social: una nueva teoría socioecológica. Relaciones, Volume 136, pp. 41-71.

UNDP, 2016. Más allá del conflicto, luchas por el bienestar. Informe Nacional de Desarrollo Humano 2015/2016, Guatemala, Guatemala: UNDP.

van de Sandt, J., 2009. Conflictos Mineros y Pueblos Indígenas en Guatemala, Amsterdam, Holanda: Universidad de Amsterdam, CORDAID.

Walter, M., 2009. Conflictos ambientales, socioambientales, ecológico distributivos, de contenido ambiental... Reflexionando sobre enfoques y definiciones., Madrid: Centro de Investigaciones para la Paz.

Walter, M. \& Urkidi, L., 2017. Community mining consultations in Latin America (2002-2012): The contested emergence of a hybrid institution for participation. Geoforum, Volume 84, pp. 265-279.

Waxenecker, H., 2013. Disputa por los recursos estratégicos: ...la interacción de poderes fácticos en el caso de Guatemala.. [Online]

Available at: https://mx.boell.org/es/2014/05/15/disputa-por-los-recursos-estrategicos-lainteraccion-de-poderes-facticos-en-el-caso-de

[Accessed 1 March 2015].

Willems, L., 2009. Mining and Indigenous Peoples in Guatemala: The Local Relevance of Human Rights., Gent, Belgium: Univeristy of Gent, Unpublished Thesis.

Yagenova, S. \& García, R., 2009. Guatemala: el pueblo de Sipakapa versus la empresa minera Goldcorp. OSAL, 10(25), pp. 65-77. 